\title{
OUTCOME EQUALITY OR EQUALITY OF RESPECT: THE SUBSTANTIVE CONTENT OF EQUAL PROTECTION*
}

\section{EDWIN BAKER $†$}

Equal protection must have substantive content. That much should be settled by the failure of all attempts to develop a coherent approach to the clause based entirely on process, rationality, or representationreinforcing considerations. ${ }^{1}$ The Supreme Court's decisions and the commentators' recommendations inevitably imply underlying substantive value commitments. Still, moral skeptics, legal realists, and some critical theorists may reject the possibility of justifying or realizing coherent, principled content for equal protection. Court decisions may actually or even necessarily represent ad hoc results of political conflict and various chance factors. If, however, judges and commentators can and do rely either on an underlying moral reality or, more likely, rely on a historically developed, western, liberal moral framework when they respond to concrete problems, their responses may exhibit greater coherence than the doubters expect. Moreover, if this normative framework goes beyond and delegitimatizes some aspects of the existing order, increased adherence to the basic framework could be progressive. If lack of clear understanding of this moral framework makes complacent acceptance of existing practices easier and makes improper analyses distorted by existing unjust practices more plausible, while a clearer understanding would provide better guidance and greater authority to challenges to existing injustice, then a clearer formulation of this normative framework would constitute a socially valuable political advance. In any èvent, a tentative belief in these possibilities provides a motive for engaging in this investigation.

At a less grandiose level, this Article will explore two "models" of equal protection that offer some promise of normative guidance. In an earlier article, I claimed to demonstrate the descriptive, analytic, and normative failure of a variety of process, rationality, or neutrality ap-

* The Article reflects suggestions made during presentations of earlier versions to the Yale Legal Theory Faculty Workshop and the University of Pennsylvania Faculty Legal Studies Seminar. Many other individuals have also made useful and appreciated suggestions. I have particularly benefited from suggestions and comments of Professor Seth Kreimer. The Article was partially supported by a summer grant from the National Endowment for the Humanities.

$\dagger$ Professor of Law, University of Pennsylvania. B.A. 1969, Stanford University; J.D. 1972, Yale University.

1 Baker, Neutrality, Process, and Rationality: Flawed Interpretations of Equal Protection, 58 TEX. L. REV. 1029 (1980). 
proaches to equal protection and tentatively suggested the superiority of what I called the "equality of respect" model. ${ }^{2}$ In contrast, liberal reformers, although usually agreeing on the inadequacy of the typically conservative process or rationality models, most often suggest, as an alternative, some version of what I will call the "outcome equality" model. This Article, first, will describe the nature and doctrinal implications of outcome equality approaches. Then, through a critique and revision of John Rawls' theory of justice, the Article will analyze the inevitable flaws of outcome equality models and describe key features of a preferable alternative, the equality of respect model. Finally, the Article will sketch some of the doctrinal features of this preferred, equality of respect approach.

\section{Outcome Equality}

\section{A. The Model}

The most obvious substantive content to read into the equal protection clause is a requirement that government achieve, or at least favor, particular egalitarian outcomes or other, specific societal results. Given its history, equal protection arguably requires either a racially integrated society or a racially equalized society-that is, a society where race is not a reliable predictor of education, wealth, power, or status. Alternatively, as suggested by modern equal protection case law and commentators, the idea of equality may sweep more broadly. ${ }^{3}$ To play with the words, one could read "protection of the laws" as the protection the law (the state) gives to a person's claim on resources and opportunities. Then "equal protection" might mean that the law or the state would protect an equal total amount of each person's claims. Thus, equal protection would require the state to protect each person's ownership of an equal share of society's resources and privileges and refuse to protect anyone's attempted possession of more than an equal share. Thus, one can easily read equal protection to guarantee an equal distribution of wealth or welfare or some other measure of society's riches. ${ }^{4}$ Because of the extreme nature of this egalitarian reading, how-

Id.

- Both history and recent Harvard Law Review Supreme Court Forewards provide ample support for Professor Cox's observation that "[o]nce loosed, the idea of Equality is not easily cabined." Cox, The Supreme Court, 1965 Term, Foreward: Constitutional Adjudication and the Promotion of Human Rights, 80 HARV. L. REV. 91, 91 (1966). See, e.g., Karst, The Supreme Court, 1976 Term, Foreward: Equal Citizenship Under the Fourteenth Amendment, 91 HARV. L. REV. 1 (1977); Michelman, The Supreme Court, 1968 Term, Foreward: On Protecting the Poor Through the Fourteenth Amendment, 83 HARV. L. REV. 7 (1969).

1 Alternatively, one could give these words a formal interpretation in which equal protection of the law would mean that the law, whatever it is, is applied in all cases in which it is applicable. 
ever, interpreters are likely to develop a more complex description of equal protection that would justify an only partially egalitarian outcome-for example, the efficient institutional arrangement that maximizes the position of the worst off groups and that, therefore, allows only those inequalities that apparently benefit everyone.

Precisely the promise of some such substantively egalitarian outcomes is the message many hopeful liberal reformers discerned in the Warren Court's equal protection innovations during the 1960's. Moreover, one suspects this type of outcome focus is the viewpoint that seems most logical, and certainly most relevant, to those looking for relief from the misfortunes and disadvantages society has in some sense imposed on them. The outcome perspective may be the natural perspective of the "victims" of societal choices."

An outcome orientation presents two crucial tasks to the equal protection theorist: first, to describe the required outcomes or to identify principles with which one can determine required outcomes; second, to justify requiring these outcomes. This justification necessitates a normative defense (assuming, as I do, that neither a linguistic nor an historical basis of interpretation of the equal protection clause is adequate), and, lest one forget that equal protection is a facet of constitutional law, the justification requires an explanation of why the required principles or outcomes are a proper implementation of the constitutional text.

Having described and justified specific content for an outcome equality model, this theory requires an evaluation of proposed or challenged government action or inaction primarily in terms of effects or impact rather than, for example, government purposes. The crucial legal issue for the outcome equality model is whether the challenged government practice advances or impedes the required outcomes.

This effects orientation has several doctrinal implications. The institutional position of the judiciary will most likely leave the courts un-

See Baker, supra note 1, at 1032-33 (noting that in the nineteenth century the Court rejected the interpretation that equal protection was satisfied by "uniform application" of essentially discriminatory laws). For a similar contrast between a formal and substantive interpretation of a similar phrase, i.e., of "same right," as used in 42 U.S.C. \$ 1982 (1976 \& Supp. V 1981), compare Jones v. Alfred H. Mayer Co., 392 U.S. 409, $452-53$ (1968) (Harlan, J., dissenting) ("same right" means the right of any person to buy from anyone willing to sell to her) with id. at 423 (opinion of the Court) ("right to purchase . . . was to be enjoyed equally . . by Negro and White citizens") (emphasis added). Although the Court in Mayer concluded that "to be enjoyed equally" requires that all racial discrimination be prohibited in the sale or rental of property, the Court would have given a more completely substantive interpretation to the "same right" if it had concluded that the right is not "enjoyed equally" by different races or by different people unless all racial groups or all people have equal resources with which to take advantage of, and thereby equally enjoy, purchase opportunities.

s See, e.g., Freeman, Legitimizing Racial Discrimination Through Antidiscrimination Law: A Critical Review of Supreme Court Doctrine, 62 MINN. L. REv. 1049 (1978). 
able fully to implement or effectively to mandate the vision of the just society, that is, the entire set of outcomes, specified by this interpretation of equal protection. A responsible court, convinced of a particular outcome interpretation, could, at best, act strategically to implement those outcomes within judicial reach as well as use the mandated vision of the just society as the value perspective with which to interpret all legislative and constitutional provisions. The outcome theory might hold that governmental values other than achieving these egalitarian outcomes have some importance and, therefore, that the court engage in a balancing analysis. The theory also might recognize that successful "strategic" judicial implementation of the theoretically identified outcomes requires an evaluation of the political consequences of judicial intervention, thus suggesting that the court consider the extent to which its decision would interfere -with major goals of the political branches of government. In both cases, courts must consider government purposes. The role of this purpose analysis, however, would not be to find and outlaw improper or impermissible purposes. The task would be to determine whether the government's purpose was important, substantial, or compelling enough to justify the government in subordinating, or the court in strategically ignoring, outcomes otherwise mandated by equal protection.

Rationality or process interpretations of equal protection are consistently instrumentalist in their analyses. ${ }^{6}$ Both rationality's overt focus on the relation of ends and means and the process approach's more general attempt to determine whether given legislation has resulted or would result from a political process that properly represented or weighed or summed political inputs are technical analyses that avoid overt reliance on controversial normative claims. The outcome model, which substitutes "objectively" determined outcomes for the neutrality model's grounding in individuals' subjective preferences, is, in a sense, doubly instrumentalist. First, it shares the neutrality model's assumption that equal protection requires measuring the achievement of actual legislation against a theoretically specified standard-for the neutrality model, either against instrumental rationality or the results of a proper process and, for the outcome model, against the outcomes demanded by its substantive ideal of equality. Second, the outcome orientation inevitably leads the judiciary into an instrumentalist, goal advancing, posture. Institutionally incapable of fully implementing the constitutional command of equal protection, the courts must instead act strategically and interstitially to advance the mandated outcomes. In both respects,

- See Baker, supra note 1 (critique of these instrumental approaches). 
the instrumentalist emphasis of the outcome equality model differs from the equality of respect model described below.

Beyond these general characteristics of any outcome equality approach, development of more precise content requires actually describing and defending a specific interpretation of equal protection. Neither judicial dicta nor scholarly consensus points to an agreed upon interpretation. Those whose arguments imply acceptance of an outcome equality approach-for example, most of those who criticize adoption of any purpose analysis ${ }^{8}$ and who advocate a pure effects analysis-usually attempt only to defend particular egalitarian or minorityoriented results and avoid providing a full description of the features of the just society that their notion of equal protection or substantive equality requires. Nevertheless, various modern theorists-Professors John Rawls, ${ }^{9}$ Bruce Ackerman, ${ }^{10}$ and Ronald Dworkin, ${ }^{11}$ for example-offer "liberal" justifications for substantively egalitarian, outcome equality models. In order to suggest the plausibility of such models in the context of existing doctrinal controversy, I will briefly describe some of the doctrinal implications of a plausible elaboration of a Rawlsian model. ${ }^{12}$ Rawls' work will serve as the primary example of an outcome equality model not only because of its depth, influence, and popularity, but also because it shares considerable ground with the equality of re-

See infra notes 155-60 \& 163-64 and accompanying text.

- Prominent cases emphasizing a "purpose" analysis, e.g., Personnel Admin. v. Feeney, 442 U.S. 256 (1979); Arlington Heights v. Metropolitan Hous. Corp., 429 U.S. 252 (1977); Washington v. Davis, 426 U.S. 229 (1976), occur in contexts where the law, on its face, does not draw a line on the basis, for example, of race or sex, but where it has a disproportionate effect on some group. One can easily conclude, following suggestions by the Court, see, e.g., Feeney, 442 U.S. at 272, 274; but $c f$. id. at 281 (Stevens, J., joined by White, J., concurring), that there are two types of analyses, an ends-means form of "scrutiny" analysis if the sex or race classification is overt and a purpose analysis if it is not. This distinction, which no one has justified, makes no sense except possibly for use in establishing presumptions in the realm of "proving" or determining something else. The position of this Article is that the concern with "purpose" or "meaning" should be (and has been) central in both the overt classifications cases and the disproportionate impact cases, but that the positivist assumption that purpose or meaning is a matter of knowledge of someone else's (e.g., the legislator's) subjectivity, is wrong. See infra text accompanying notes 94-141. Although there are other forceful reasons to focus on effects, I suspect that a significant reason many progressive lawyers and commentators advocate an effects analysis is that they assume a purpose analysis could only be an inquiry into subjective intent.

- J. RAWLS, A THEORY OF JUSTICE (1971).

10 B. ACKERMaN, Social JUSTICE IN THE Liberal STATE (1980).

11 Dworkin, Liberalism, in PUBLIC AND PRIVATE MORALITY 113 (S. Hampshire ed. 1978); Dworkin, What Is Equality? Part I: Equality of Welfare, 10 PHIL. \& PUB. AFF. 185 (1981); Dworkin, What Is Equality? Part II: Equality of Resources, 10 PHIL. \& PUB. AFF. 283 (1981).

12 In a series of articles, Professor Frank Michelman has carefully developed, evaluated, and extended a partially Rawlsian inspired theory. See, e.g., Michelman, The Supreme Court, 1968 Term, Foreward: On Protecting the Poor through the Fourteenth Amendment, 83 HARV. L. REV. 7 (1969); Michelman, In Pursuit of Constitutional Welfare Rights: One View of Rawls' Theory of Justice, 121 U. PA. L. REV. 962 (1973). In some respects, Michelman's approach may be consistent with either the outcome equality or equality of respect models as presented herein. 
spect model, which I will derive in part through a critique of Rawls' approach.

Any justification for an outcome equality model as an interpretation of the constitutional language will be complex and controversial. The most plausible theoretical justification for either the outcome equality or equality of respect model will begin, I believe, with the notion that all people (or, at least, all members of the relevant community) ${ }^{13}$ rightfully can demand that the community treat them with full and equal respect and concern as autonomous persons. Such treatment is a necessary part of the justification for the community's claim that all members have an obligation to abide by the rules or mandatory norms of the community. ${ }^{14}$ (This basic notion that people must be treated as equals will be called the "equality of respect principle"15 — which must be distinguished from the equality of respect model or approach that is developed in part II and that is only one of the principle's possible interpretations. The outcome equality and the equality of respect models should be seen as alternative interpretations of the equality of respect principle. Of course, one could base either model on other premises, but, in my view, the equality of respect principle provides both with their best grounding. $)^{\mathbf{1 6}}$

1s The political community includes noncitizens even though they are properly denied the right to vote. See Karst, The Supreme Court, 1976 Term, Foreward: Equal Citizenship Under the Fourteenth Amendment, 91 HARV. L. REV. 1, 25 (1977) (the principle of equal citizenship, which is at the core of the fourteenth amendment, is broader than the legal status of citizenship and applies to aliens). But cf. Perry, Modern Equal Protection: A Conceptualization and Appraisal, 79 COLUM. L. REV. 1023, 1061-62 (1979) ("alienage is conventionally . . . regarded as a morally relevant status" and, thus, most discrimination against aliens does not "implicate the principle of equal protection" although it may violate federalism principles). Arguably, a nonmember does not have the same claim either to participate in community decisionmaking or to receive benefits provided by the community as does a member, but the nonmember does have a claim to be treated as a person; this claim would rule out certain forms of discrimination or inhumane, disrespectful treatment. Membership provides a more strongly based solidarity from which increased obligations of the group arise within the sphere of membership. Possibly this same distinction can partially inform other aspects of constitutional law, for example, the different due process rights one receives when one applies for a job (seeks to become a member) and when one's employment is terminated (membership is discontinued).

16 The need to justify obedience to the law is possibly the key task that modern legal and political theory sets for itself. See R. UNGER, KNOWLEDGE AND POLITICS (1975). For example, both Rawls and Ackerman undertake to determine the substantive conditions that would justify legal obligation or, more generally, any power structure. See J. RAWLS, supra note 9, at 167; B. ACKERMAN, supra note 10, at 8-10. Principles that serve this function are appropriately placed in the fundamental law that overrides other democratically arrived at, or otherwise welfare promoting, decisions.

1s As used herein, the "equality of respect principle" refers to the general view that the community must treat all of its members with full and equal respect and concern as autonomous persons-a principle that leads to interpretations of the first amendment, the equal protection clause, and possibly other constitutional provisions. Both the "outcome equality" and "equality of respect" models or approaches or interpretations refer to interpretations of equal protection, which will amount to particular, competing elaborations of this equality of respect principle.

18 The assumption that the equal protection clause embodies such an equality of respect 
To move from the general premise that the state must recognize people's claim to equal concern and respect to a conclusion that mandates particular social or distributional outcomes requires detailed connecting arguments. Rawls' theory of justice provides a potential connective. First, his theory uses various expository devices to develop the implications of his fundamental value assumption-that the social structure should respect the "equality between human beings as moral persons." Rawls tries to determine the principles for evaluating the basic institutions of society that a person would choose if she had no specific information about herself or her society. Since, under this constraint, the chooser has no basis to guess who she is or what her values or talents are, a rational, self-interested chooser would most likely choose to treat the interests of everyone as equally worthy of advancement $^{18}$ - that is, she would treat everyone with equal concern and re-

principle is not historically incongruous. The institution of slavery is our history's most glaring violation of this principle. Slavery denies that some people are fully and equally important, autonomous agents; accordingly, society cannot legitimately expect voluntary obedience from slaves. The thirteenth amendment outlaws slavery as the most dramatic violation of the equality of respect principle. One can read the Civil War era amendments as a group, and particularly the fourteenth amendment which speaks most generally, as rejecting any violation of the principle. Thus, ending racial subordination becomes only the first, the then most pressing but now, hopefully, the least controversial, application of this normative principle institutionalized in the fourteenth amendment. The defense of this conclusion as being a result of a proper method of constitutional interpretation, which views the purpose of this constitutional provision at a particularly high level of generality, is postponed.

$17 \mathrm{~J}$. RAWLS, supra note 9, at 19, 75; see also id. at 11, 13.

18 The veil of ignorance "forces each person in the original position to take the good of others into account." Id. at 148. One might assume this results because, without any knowledge about oneself, one could equally turn out to be anyone and, hence, should take the good of each person into account. However, in rejecting the argument for the choice of average utilitarianism, Rawls states that "there seems to be no objective grounds [sic] in the initial situation for assuming that one has an equal chance of turning out to be anybody." Id. at 168 . This denial may be part of a possible Rawlsian response to the common objection that Rawls' analysis appears to depend on assuming that the people in the original position are very risk averse. Rawls claims that it is essential that the principles chosen do not depend on special attitudes toward risk. Instead, he requires a demonstration that unique features of the choice situation make it rational to choose as if one had such an aversion to risk. His emphasis on the fact that one must choose principles that one would "be able to honor . . . under all relevant and foreseeable circumstances," id. at 175, may contribute to this result. A gambler might be willing to risk being a slave in order to receive a good chance of being well-off and, if she turned out to be the slave, might even agree that she would have taken the gamble. Still, she might find the deprivation so intolerable that she would still revolt (even while recognizing that she would have agreed to institutions that enslaved her). As long as in practice she would try to overthrow the condition or, more to the point, as long as some people would not accept the resulting deprivations, a person choosing behind the veil of ignorance would have to choose as if she were risk averse in order to assure that she would be able to honor the agreement. Under the circumstances, she would choose less from the perspective that she has an equal chance to be anyone and more from the perspective that she must find it acceptable that she be anyone. In a sense, this becomes an interpretation of the type of universal legislation Kant requires under the categorical imperative-a proper rule of conduct no matter who the phenomenal self turns out to be. See I. KANT, FOUNDATIONS OF THE METAPHYSICS OF MORALS *421 (L. Beck trans. 1959). (If I correctly understood him, I am indebted to George Fletcher for these observations.) 
spect. Second, in Rawls' theory, this choice of principles of justice occurs under circumstances where the choosers apparently must adopt an outcome orientation. ${ }^{19}$ At least Rawls' development of his argument seems to lead to this outcome orientation. By treating people behind the veil of ignorance as concerned with maximizing receipt of "primary goods," Rawls necessarily implies that, at least for purposes of choosing basic principles of justice, people should treat their welfare as primarily dependent on the availability of resources that may be instrumentally useful for achieving their more specific personal goals. Thus, Rawls' theory of justice leads us from equality of respect to a focus on institutionally generated distributional outcomes.

Rawls' conception of justice requires that major social institutions distribute primary goods equally except to the extent that an unequal distribution advantages the worst off group. The norm is equality. Rawls' "difference principle" only allows deviations from equality in the distribution of wealth and income when the deviation benefits the worst off. Although a "social minimum"-i.e., a guaranteed income-might provide the best institutional arrangement for implementing Rawls' difference principle, the Rawlsian might find that a more effective way of maximizing the position of the worst off would rely, at least in part, on guaranteeing the provision of "just wants"-for example, guaranteed medical services, food stamps, public housing as well as cash welfare payments. A "just wants" approach may allow greater redistribution with less disruption of the incentive structure and with less reduction in total production. Moreover, a just wants guarantee might better protect against unacceptable outcomes. ${ }^{20}$ In any event, a

19 See R. NOZICK, ANARCHY, STATE, AND UTOPIA 201-02 (1974). Nozick says that the nature of the decision problem facing people in Rawls' original position "limits them to end-state principles of distribution," $i d$. at 201 , and that any end-state principle requires "continuous interference with peoples' lives," id. at 163. Of course, any legal order or lack of legal order interferes with peoples' lives as compared to some other order. See Kennedy \& Michelman, Are Property and Contract Efficient?, 8 HOFSTRA L. REv. 711, 724 (1980). Nozick, though, suggests a picture of the Rawlsian state continuously, coercively, rearranging distributions and relationships after each exercise of choice (of liberty) by individuals-e.g., the state must intervene after each exchange or gift that causes a deviation from the required distribution. This picture of Rawls' conclusions is wrong - a point that I must make because my later criticism of Rawls' outcome orientation could be confused with Nozick's. Rawls requires that major social institutions be evaluated, selected or rejected, in terms of the outcomes the evaluator can expect them to produce. As both courts and theorists have long recognized, people have liberty rights within, and only within, some set of institutions or practices. Choosing a set of institutions on the basis of desired outcomes does not require constant interference with liberty but, the outcome theorist might argue, does provide the optimal arrangement for exercising even the negative liberty with which the libertarians seem so concerned. See Kronman, Contract Law and Distributive Justice, 89 YALE L.J. 472 (1980). Nevertheless, I will argue below, contrary to Rawls, that given Rawls' characterization of the original position, the parties would not choose "end-state principles of distribution" even to evaluate basic institutions.

${ }^{20}$ Cf. J. RAWLS, supra note 9, at 154, 156, 169, 176 (importance of avoiding unacceptable outcomes). 
Rawlsian oriented constitutional court strategically is better situated to help implement the difference principle by focusing on just wants than on minimum income levels.

Rawls' difference principle, combined either with plausible assumptions concerning the incentive structure or with a recognition of the institutional position of courts, offers plausible explanations for and possible extensions of modern equal protection doctrines. First, Rawls recognizes that justice requires "efficient" institutions-society should always institute those changes that make someone better off without making anyone worse off. ${ }^{21}$ Equal protection's odd rationality requirement would implement this efficiency mandate if the requirement identified laws that were so costly in relation to any benefits produced that both the worst off groups and society as a whole would be better off without the law. Beyond the need for minimal instrumental "rationality," the courts should hesitate before intervening in the area of "economic and social regulations." Usually it is unclear which regulations would be in the long-run interests of the worst off. Some economists reject common intuitions and argue that most protective labor laws, price and rent controls, and consumer protection laws disadvantage the poor. President Reagan and perhaps his judicial appointees claim to believe that the position of the poor will be most improved if the government rewards corporations for increasing investment and production: what's good for General Motors (and the energy companies and ....) is good for the poor (as well as for the banks and brokers). In any event, the prudentially oriented, popularly controlled, political branches of government should be at least as capable of resolving these debatable factual issues as are the courts. Given this capacity, both greater legitimacy and, possibly, better results for the worst off will result if courts defer to legislatures on these issues. ${ }^{22}$

The analysis changes if the government acts to subordinate groups that are already among the less well off or if it limits people's opportunities to fulfill basic needs. Thus enter the suspect classification, fundamental rights, compelling state interest, and least restrictive alternative doctrines. Laws that burden groups primarily composed of the "worst off" members of society should be suspect. Both these burdens and any limitations on the fulfillment of basic needs will seldom advance the

32 Id. at $66-67,79-80,82-83$.

22 Of course, if one recognizes that Reagan's objective is to "transfer" wealth from the poor to the rich, the Rawlsian analysis would require rejection of his policies; the Rawlsian court would be forced to invalidate. Partly in order to avoid constant intervention, partly in recognition of political realities, a Rawlsian judge may, in practice, officially blind herself to political reality, proclaiming deference except during moments when she can intervene strategically, for example, in her interpretation of laws. 
interests of the worst off. Nevertheless, if the burdensome law advances a sufficiently "compelling" state interest the law might benefit all of society, including the worst off, even though the law, to some lesser degree, subordinates particular interests of the worst off or impedes the adequate fulfillment of basic needs. Then the worst off would be better off accepting the important societal gains and having their more specific interests advanced in less costly ways. The deprived group should still object, however, if a "less restrictive alternative" could achieve this compelling end. Moreover, a properly developed "sliding scale" analysis would recognize that the degree of benefit or compellingness necessary to justify the law must increase the more those disadvantaged by the law are among the society's worst off, the more severely the law disadvantages that group, or the more basic is the need that the law leaves unfulfilled.

Since the effect on the disadvantaged group and not the purpose of the law is crucial, the outcome equality model is not sensitive to the difference between the laws that amount to offers (inducements) and those that invoke threats (coercion or penalties). ${ }^{23}$ From the outcome equality perspective, the distinction is pointless in the context of laws burdening the worse off or impeding fulfillment of basic needs since poverty itself "coerces" when the government imposes any conditions on the availability of basic necessities-a view of coercion that is, of course, correct given the outcome equality model's premise that guaranteed fulfillment of just wants is the appropriate base line.

Finally, since the courts are ill-equipped to remedy or even to identify all the ways in which society fails to maximize the position of the worst off, the outcome equality perspective explains the notion, so difficult for the positivist to accept, of a right institutionalized but not fully protected by a constitutional provision. ${ }^{24}$ Section five of the fourteenth amendment, which grants Congress the "power to enforce, by appropriate legislation" the provisions of the amendment ${ }^{25}$ does not give Congress the power to say what equal protection means-the out-

${ }^{23}$ Although the majority in Maher v. Roe, 432 U.S. 464 (1977) (state denial of abortion funding), and Sosna v. Iowa, 419 U.S. 393 (1975) (residence requirement for divorce), arguably were wrong not to find that the law imposed a penalty, the dissents' focus on effects left the dissents relatively unable to distinguish a burden from a penalty. A successful penalty argument would require a showing that something to which the burdened party had a right was intentionally denied her or, alternatively, that the burden reflected or was imposed because of an at least implicit negative judgment by the state concerning an act in which the burdened party had a right to engage.

s4 See, e.g., United States v. Guest, 383 U.S. 745, 774-86 (1966) (Brennan, J., joined by Warren, C.J., and Douglas, J., concurring in part and dissenting in part); see also infra text accompanying notes 155-60.

${ }_{28}$ U.S. CONST. amend. XIV, \& 5. 
come equality model adequately specifies its meaning-but instead gives Congress the power to take action, for example, to advance more fully the interests of the worst off. ${ }^{28}$ This reliance on Congress follows not from the theoretical lack of precision of the equal protection standard but either because the courts' institutional position leaves them strategically ill-equipped to implement fully equal protection's mandates or because the courts are not suited to make the economic, instrumentalist calculations or factual predictions that are necessary to justify the specific laws. Of course, as its advocates have recognized, this argument for special congressional power only provides a principled justification for Congress to move beyond what the courts can implement-not for backtracking. ${ }^{27}$

Further development of the implications of Rawls' principles of justice-or some alternative theory that also evaluates effects in terms of, or that mandates particular outcomes that conform to, particular substantive principles-is necessary before the outcome equality approach will be precise enough to decide actual cases. Nevertheless, this quick survey should suffice to demonstrate that an outcome oriented approach could provide powerful and discriminating explanations for many presently accepted as well as other, presently advocated strands of equal protection doctrine. The next step in understanding-and eventually abandoning - the outcome equality approach requires examining the theoretical justifications that can be, or have been, given for it.

\section{B. The Critique: The Irrationality of Outcome Equality Models}

\section{The Need for Normative Theory in Constitutional Interpretation: Legitimizing the Political Order}

Before specifically examining outcome equality, one ubiquitous objection to all substantive theories of equal protection merits comment. Equal protection, it is argued, is too important to change with the fads of Cambridge (Massachusetts) political philosophy. ${ }^{28}$ Fundamental law ought to have an objective, stable meaning instead of one that varies

20 This interpretation of section five does not contradict the argument, infra text accompanying notes $47-48$, that the outcome equality model eliminates politics in the sense of a collective process of making value judgments. Instead, like the Rawlsian theory, it leaves only a responsibility for legislative factual judgments concerning the best way to achieve theoretically specified outcomes. See infra notes 48 \& 60-61; text accompanying notes 60-62.

27 Justice Brennan develops arguments of this sort. See Oregon v. Mitchell, 400 U.S. 112, 229-81 (1970) (Brennan, White \& Marshall, JJ., dissenting in part); United States v. Guest, 383 U.S. 745, 781-86 (1966) (Brennan, J., joined by Warren, C.J. \& Douglas, J., concurring in part and dissenting in part); Katzenbach v. Morgan, 384 U.S. 641 (1966).

is Or, worse, follow the latest trends in the New York Review of Books. See J. ELY, DEMOCRACY AND DISTRUST 58 (1980). 
with the judge's idiosyncratic preference among various, constantly disputed, constantly changing, never universally accepted, political and moral philosophies. Surely, if the Constitution does not enact Herbert Spencer's or Karl Marx's social ethics, it also does not enact those of Robert Nozick or John Rawls.

This objection to adopting substantive theories of equal protection, with its implicit backward glance at the Lochner ${ }^{29}$ era of economic due process, is misguided. The failures of the process or neutrality approaches to equal protection illustrate that judicial decisions cannot apply constitutional provisions without at least implicit reliance on normative assumptions. ${ }^{30}$ Nor can judicial decisions avoid making often controversial, empirical assumptions about the nature of the world. The most observable shift between Lochner v. New York ${ }^{31}$ and West Coast Hotel Co. v. Parrish ${ }^{32}$ was less a shift in the Court's doctrinal and value commitments than in its empirical visions. ${ }^{33}$ If one viewed the world, as the Lochner court did, as one where (1) people are basically independent and (2) their rights exist prior to or independent of the institution of a social order that is created to protect these rights and promote the welfare of all, then one could distinguish between legitimate laws that serve these general public purposes of the social order and illegitimate laws that instead serve private interests by abridging some people's rights in order to favor others-i.e., laws that take from $A$ in order to give to $B .^{34}$ Given these empirical assumptions about social life, a voluntary exchange of rights could not be exploitative ${ }^{35}$ or involve any public subsidy; rather, an exchange between informed, responsible parties normally would be a mutually advantageous exercise of liberty. ${ }^{38}$ Therefore, since as the majority thought, the "labor law"

28 Lochner v. New York, 198 U.S. 45 (1905).

so See Baker, supra note 1 .

31198 U.S. 45 (1905).

300 U.S. 379 (1937).

so The distinction between value and empirical visions is overstated for purposes of making the argument in the text. My claim is that the shift from Lochner was not merely the result of some people having (or choosing) different values. Instead, when, for whatever historical reasons, people saw the world the way it was described in West Coast Hotel, any attempt to apply the doctrines accepted in Lochner would lead to the abandonment of the holding in Lochner as well as the courts' capacity to find violations of substantive due process.

* See, e.g., Wilkinson v. Leland, 27 U.S. (2 Pet.) 627, 658 (1829) ("We know of no case, in which a legislative act to transfer the property of A. to B. without his consent, has ever been held a constitutional exercise of legislative power . . . ."); Calder v. Bull, 3 U.S. (3 Dall.) 386, 388 (1798) ("a law that takes property from A. and gives it to B.") (emphasis in 1799 ed.). This popular conception was used to emphasize the importance of distinguishing private from public purposes, see, e.g., Loan Ass'n v. Topeka, 87 U.S. 655, 663 (1874), and became identified with due process, see, e.g., Davidson v. New Orleans, 96 U.S. 97, 102 (1877).

${ }^{3 s}$ See R. NozicK, supra note 19, at 253-65.

so In contrast, if people were not independent and only had rights that emanated from the social order, then allowing employers to reach bargains that left their employees impoverished 
in Lochner clearly did not serve the public purposes of safety, health, morals, or welfare, its real purpose must have been to promote private interests-a purpose in opposition to the rationale for having the law of the land in the first place, a purpose that enlists the state's coercive force in order to deny people their due. But if, as the Court assumed in West Coast Hotel, people are basically interdependent ${ }^{37}$ and if people's rights exist only within a social order, if "the liberty safeguarded is liberty in a social organization,"3s then a person would have only what the law or the social order provides and, therefore, a court would have no analytic way of identifying a taking from $A$; moreover, given the interconnections between $B$ and others, $B$ 's benefit might well serve the general good. A court would then find that it has no criteria for identifying what constitutes the public welfare other than by looking to the results of a properly functioning political process. There would be no standpoint from which to distinguish laws that advance private as opposed to public welfare. Thus, even without the Court changing its general interpretation of due process ("regulation ... adopted in the interests of the community is due process"), ${ }^{39}$ the Court's new, somewhat more accurate view of the actual nature of social life mandated dramatically different judicial holdings. The Court might continue to uphold only legislation that promoted the public welfare, but it would have no place to look to determine the content of the public welfare other than the legislation itself. ${ }^{40}$ But whether or not the Court also changed its normative views, ${ }^{41}$ what it certainly did not do in West Coast Hotel was abandon reliance on social and economic theories about the nature of social life; rather, its change was to rely upon different, better theories. Inevitably, some such social or economic theories, as well as necessarily value laden theories about the appropriate normative content of constitutional provisions, are implicit in interpretative judgements that either the constitution was or was not violated.

Given this inevitability of reliance on both social theories and nor-

would involve "[t]he exploitation of a class of workers who are in an unequal position with respect to bargaining" and "provide what is in effect a subsidy for unconscionable employers." West Coast Hotel, 300 U.S. at 399.

${ }^{37}$ See supra note 36. The exploitation of some workers "casts a direct burden for their support upon the community." West Coast Hotel, 300 U.S. at 399. "The whole is no greater than the sum of all the parts, and when the individual health, safety and welfare are sacrificed or neglected, the State must suffer." Id. at 394 (quoting Holden v. Hardy, 169 U.S. 366, 397 (1898)).

20 West Coast Hotel, 300 U.S. at 391.

so Id. at 391 . The Court also said that the regulation must be "reasonable in relation to its subject." Id.

10 The Carolene Products footnote is a rather obvious type of response to this circumstance. See United States v. Carolene Prods. Co., 304 U.S. 144, 152 n.4 (1938).

41 Apparently the Court's value and empirical commitments, which presumably are interdependent, see supra note 33, both changed between Lochner and West Coast Hotel. 
mative assumptions, one should not criticize a judge or commentator for relying on not only the most accurate social and economic perspective available but also the most coherent, the best defended, normative perspective she can find. ${ }^{42}$ Although the Constitution does not name John Rawls' theory of justice, one must recognize the possibility that the Harvard philosophers who view their job as uncovering, interpreting, and subjecting to criticism our ethical values, will provide the best, presently available interpretation of our normative commitments from which a judge can and should receive guidance. To demand that judges ignore careful normative and empirical investigations and, instead, interpret constitutional provisions on the basis of something else-gut feeling, "common sense," or explicit prejudices-is inconsistent with the demand that judges be reflective, principled, and self-conscious in performing their role. Rather than loudly condemn reliance on philosophical perspectives, the serious critic must ask: Is the particular normative perspective relied upon the most persuasive available? Does it provide the best ordering and defense of our moral intuitions? Does it relate to the problem of interpreting either a particular provision or the structure of the Constitution? These are the questions to ask of any substantive constitutional theory.

The main reason to begin the critique of the outcome equality model with an examination of John Rawls' theory of justice is that the attempt to correct certain difficulties with his formulation helpfully leads to what I argue is the better, equality of respect model. This starting point, however, also makes sense for other reasons. First, despite being subject to widespread criticism, Rawls' theory may be the best, most powerful and systematic, and most influential substantive equality theory presently available. Second, Rawls' approach avoids key mistakes that detract from a number of competing theories. Unlike Robert Nozick, Rawls properly distinguishes the task of evaluating so-

62 Sometimes theorists try to escape this problem by relying on "process values." For example, democracy, they may argue, is and should be the fundamental value, or is the premise that we do accept and on which our constitutional structure is built, or is simply a convenient principle to rely upon to avoid value judgments. These arguments, however, do not show why democracy should be accepted or what form of democracy should be accepted. If one tries to answer these questions, one may find that our acceptance of democracy is itself part of the embodiment and part of the evidence of our acceptance of broader value commitments. These broader value commitments may not only justify democracy but may also justify limits on democracy. In other words, discussion cannot properly end with the invocation of democracy; the best arguments for relying upon democracy may also require limitations. Elsewhere I have emphasized this rather simple, but frequently ignored point. See, e.g., Baker, Counting Preferences in Collective Choice Situations, 25 UCLA L. REV. 381 (1978) (arguing that equality and liberty values sometimes require ignoring some preferences) [hereinafter cited as Baker, Counting Preferences]; Baker, Flawed Interpretations, supra note 1; Baker, Realizing Self-Realization: Corporate Political Expenditures and Redish's The Value of Free Speech, 130 U. PA. L. REV. 646 (1982). 
ciety's major institutions and structure from the task of evaluating individual conduct which necessarily occurs within some societal framework; ${ }^{43}$ and unlike most utilitarians, Rawls avoids giving controlling influence to existing preferences or values that are themselves objectionable because they reflect unjust structures of domination.

Third, in important respects, Rawls' intellectual enterprise closely duplicates the interpreter's task in understanding the more general, justice oriented clauses of the Constitution. ${ }^{44}$ For each, the key interest or motivation in giving content to a basic agreement is to describe the organizing principles or structure of a legitimate legal order. Rawls envisions a hypothetical contract to which people neither actually agree nor, in the case of many people, would agree (since the content of the hypothetical contract does not, as compared with our existing social structure, promote their actual interests) but which, Rawls argues, still has important normative relevance. He uses this contract analysis as an expository device to show the necessary features of a legitimate social and legal order. Rawls assumes that a person could properly complain if the social order did not respect her worth as much as anyone else's but that a person could not properly ask for more. He then attempts to embody this equality requirement in his formulation of the "original position"- a construct in which one chooses principles without having the information with which to design principles that benefit one's self over others. The "choice" of fundamental principles under self-enforced

43 Nozick complains that Rawls' assumption that different principles apply in the micro and macro cases precludes easy evaluation of Rawls' principles and argues that the distinction is, therefore, undesirable. R. Nozick, supra note 19, at 204-06. Nozick suggests that "[t]he only reason . . . for discounting microtests of the fundamental principles is that microsituations have particular entitlements built into them"-a reason Nozick finds unpersuasive. Id. at 206. Contrary to Nozick's conclusion, that is a good reason to discount microtests. Moreover, although Nozick and Rawls agree that microsituations have entitlements built in, Nozick claims that Rawls' position commits him to the view that no entitlements exist at a level that underlies the microlevel entitlements, and therefore, that no fundamental entitlement view is correct. This does not follow. Rawls need only claim that not all microlevel entitlements are fundamental. Then the role of the principles of justice would be to choose among possible systems of microlevel entitlements. Rawls does assume that some entitlements, or what can be called "entitlements," exist at the macrolevel-e.g., a right to equality of respect as a person. Apparently, Nozick's real objections are, first, that Rawls thinks it necessary (and possible) to consider what principles justify-or what principles should guide society in establishing - microstructure entitlements and, second, that Rawls assumes that the principles that guide the choice of micro-entitlements differ from the principles, namely, the micro-entitlements, that guide or limit individual action within society. If this is Nozick's point, then Rawls is right. By never developing a theory explaining which acquisitions and transfers are just or what fundamental entitlements exist, Nozick fails even to face the questions with which Rawls is concerned: uncovering principles with which to evaluate different institutional arrangements, and different entitlement and transfer theories.

4t Although I will not develop the claim in this Article, I think the appropriate form or method of interpretation and the appropriate weight to be given such factors as textual language, historical change, framer's intent, ethical theory, and precedent varies depending on the purpose or function or role within the constitutional structure that one can reasonably attribute to the provision one is interpreting. 
"ignorance" presumably provides plausible content for a social order that everyone would desire as long as everyone recognized everyone else's equal worth as an end. Individuals might prefer a different order; many wealthy or powerful individuals might prefer the existing order in the United States. Still, given that rights only exist within some collective order, those comparatively advantaged individuals can legitimately expect others to abide by social or legal rules only if the collective order equally respects the worth of each as an end-that is, Rawls concludes, the legitimacy of legal obligation depends on the rules being congruent with this hypothetical contract.

Once one abandons the framer's (or ratifier's) intent or canonical language as adequate or appropriate foundations for constitutional interpretation, the goal of interpretation arguably becomes quite similar to the goal of finding a hypothetical agreement in Rawls' theory. In fact, at one level of generality, one can plausibly treat the framers of the Constitution as trying to set up a legitimate political order. In practices like legislative and judicial proceedings, in which interpreters give the constitutional text content that is socially constitutive, they should place great emphasis on this general purpose of setting up a legitimate political order. This orientation toward, or "interest" in, interpretation follows even more readily given the interpreters' institutional (as well as personal) need to defend the legitimacy of the rights and obligations recognized in their particular decisions. This interest, in other words, ought to be partially constitutive of the judicial role. A key function of the institution of which judges are a part-a purpose served by the rule of law in general and the Constitution in particular-is to provide a basic, self-legitimizing framework through which individuals and the collective can take initiatives and resolve conflicts. In this sense, the guiding interest in finding content for the otherwise opaque constitutional text is the same as for the guiding purpose in designing Rawls' hypothetical agreement. Of course, the judge has additional institutional obligations. Operating as an expositor of a positive legal order, the judge, in a constitutional case, must render her decision as an interpretation of legal materials that include, most prominently, the constitutional text as well as precedent. Still, the more general aims of the constitutional enterprise should guide the judge in choosing particular constitutional interpretations. Specifically, the more general aim to impose requirements or apply principles that promote the legitimacy of the political order makes constitutional interpretation, particularly of the open ended, justice oriented clauses, resemble Rawls' enterprise. 


\section{Rawls' Theory of Justice}

Rawls begins by trying to elaborate conditions of choice that embody each person's claim to an equality of respect and concern as a person. ${ }^{45}$ I will not quarrel with this starting point. Rawls then argues that people in this choice situation would agree on his general conception of justice, that "[a]ll social primary goods-liberty and opportunity, income and wealth, and the bases of self-respect-are to be distributed equally unless an unequal distribution . . . is to the advantage of the least favored," or, more specifically, they would agree to his two principles, in lexical order, which guarantee, first, the greatest equal liberty and, second, social and economic inequalities "arranged so that they are both (a) to the greatest benefit of the least advantaged [the difference principle] and (b) attached to offices and positions open to all under conditions of fair equality of opportunity." $\mathrm{M}$ I will argue that Rawls is wrong to think that the equality of respect premise leads either to his two principles or to any other timeless, ahistorical conception of justice that is adequate to determine the content of the proper social order. In making this argument, initially I will note one intuitive objection to his substantive conclusion, and then will outline the general structure of a persuasive set of arguments frequently leveled against his two principles. Next, I will examine a possible modification of Rawls' original position intended to respond to these objections and reject the modification because it raises a new problem: sanctifying the status quo. Finally, the next section will return to the choice situation in Rawls' original position and describe an alternative choice of principles that avoids the objections leveled against his principles. The explanation for this alternative choice will illustrate why the outcome equality theorists' aim of establishing timeless principles of justice is misdirected. This alternative will be the equality of respect model.

\section{a. The Intuitive Objection: Eliminating Politics}

According to one persistent criticism, liberal political theory improperly tries to eliminate the role of politics and transform government into mere administration. The liberal theorist abstractly determines the general goals and duties of government; this leaves actual governments only the instrumental task of implementation. Alternatively, the liberal pluralist sees politics as merely a more or less effective means to combine conflicting private interests and treats government as the body that

45. RAWLS, supra note 9 , at $11,13,19,75$.

is Id. at $60,83,302-03$. 
announces, administers, and polices the resulting compromises. In contrast, critics of this tendency in liberal theory assert that an important aspect of the human good is the collective process of determining our values and the structures in which we live. If freedom means self-determination, freedom requires that we be involved in these collective tasks of choosing and forming the constitutive structures which over time will influence what we will be. The two most important concepts of liberty, opportunity for development and realization of the self, and opportunity for self-determination, both require maintaining the opportunity to be actually involved in the process of deciding the structure of our institutions and the content of our moral principles.

This criticism of liberal theory applies to Rawls' theory of justice. By abstractly deriving within the original position the two basic, regulative principles of justice, his theory implies that it is ethically inappropriate for actual living individuals with their historical and personal uniqueness to determine the appropriate form of basic social institutions. By relying upon this hypothetical choice that is made under the veil of ignorance, Rawls intentionally makes the basic regulative principles of the just society independent of people's knowledge of their own and others' concepts of the good as well as independent of their historical struggles and their historical circumstances. ${ }^{47}$ In Rawls' just society, government should merely maintain those institutions that most effectively embody the two principles. Government officials are expected to measure actual or proposed laws, policies, and institutions by a theoretically derived standard such as Rawls" "difference principle" (i.e., maximizing the income and wealth of the least advantaged). Presumably, different institutional arrangements will have different impacts on the distribution of wealth and income. Rawls' difference principle dictates which institutional arrangement should be implemented-specifically, the one that maximizes the wealth and income of the worst off. Thus, his principles leave no fundamental value choices to political debate or collective decision. They eliminate any substantive role for politics. ${ }^{48}$

47 The form of the institutional embodiment of Rawls' two principles of justice may vary with historical or other empirical factors but the proper form is, at least in theory, determined, probably uniquely determined, by the application of the principles to the given historical possibilities without the need for any new human value choices or debate.

4s 'To the contrary, one might view Rawls' argument as a political appeal, a contribution to political debate, and view implementation of his two principles, for those who accept his argument, as a political goal. Much political debate and political struggle would be called for in order to realize his just society. These observations do not undermine my conclusion that he leaves no room for politics if, as I would argue, politics is the activity of collectively making as well as realizing or embodying value choices. Implementing Rawls' two principles is primarily strategic behavior. Such behavior is vitally important but is not the activity of value choice that is central to politics. Advocacy of the two principles does come closer to what is meant by politics. Still, to the extent that one sees Rawls' arguments as akin to a moral geometry, J. RAWLS, supra note 9, at 121, his 
But if the activity of political choice is both a part of people's good and an aspect of people's basic liberty, eliminating this activity is intuitively objectionable.

The above description may mischaracterize Rawls' theory. ${ }^{49}$ Rawls emphasizes the role and importance of political participation and liberty. ${ }^{50}$ Only greater equal liberties, which are the concern of his first principle, and not economic and social benefits, the subject of the difference principle, justify limits on majority decisionmaking. ${ }^{61}$ Political choices, not the principles of justice themselves, determine whether the society adopts a capitalist or socialist economic system. ${ }^{\mathbf{5 2}}$ Resolution of many basic issues is apparently left to political or collective choice. Thus, although my critique (and the present intuitive objection concerning the elimination of politics) may still apply to those outcome theories that do abstractly specify the institutions and laws that a society should contain, as a critique of Rawls, it may miss the point.

Nevertheless, I do not think a proper interpretation of Rawls can accord a place for a real political sphere, defined as a realm in which people determine what sort of society they want and what sort of people they want to be or become. ${ }^{58}$ For example, consider the possibility that a particular set of laws and institutions would maximize the welfare of the worst off. If applied, the difference principle would require adoption of these laws. The alternative, that people would have the basic political right to choose some alternative set of laws and institutions that fail to maximize the position of the worst off, would exist only if the difference principle plays no role in determining the social

argument appears to deny the priority of choice, self-determination, or politics as appropriate (although possibly inevitable) within the debate. More fundamental is the objection that implementation of the two principles would, as its ideal, eliminate any proper role for politics within the just society. The objection, then, is not that Rawls' theory eliminates politics-obviously an absurd position-but that as an ideal it calls for the elimination of politics. As will be explained below, see text accompanying notes 49-62, even on this reading, my interpretation is at best controversial. Nevertheless, given that my objective is not to criticize Rawls' conclusions, but to use an interpretation of his argument as an example of an outcome equality approach and to use the critique as a step to a better argument, I would still want to employ this interpretation even if unfaithful to Rawls, although, then, apologies to Professor Rawls would be in order.

10 The following objection to my account was suggested during discussion of an earlier draft of this paper at the Yale Legal Theory Workshop. I would guess that my characterization does misrepresent Rawls' personal views. I claim, however, that it correctly represents the logic and implications of the theory as presented in A THEORY OF JUSTICE, supra note 9. If the incongruence between theory and intuitions exists-in Dworkin and Ackerman as well as Rawls, see supra notes 9-11-it may point to a deeper problem in liberal theory, one relating to the inadequate attention paid to history, community, and politics.

so J. RAWLS, supra note 9, at 221-28.

31 Id. at 229.

s2 Id. at 195-96, 258, 280-81.

ss But cf. id. at 227 ("By presenting conceptions of the public good and policies designed to promote social ends, rival parties seek the citizens' approval in accordance with just procedural rules ...."). 
structure-a result clearly unintended by Rawls and inconsistent with the popular impression that Rawls' theory and, in particular, the difference principle, does provide a standard with which to evaluate and choose among proposed institutional arrangements. ${ }^{\text {st }}$

Possibly because our institutions and traditions place such importance on political liberty, Rawls uncritically accepts democracy as an obvious aspect of "greatest equal liberty" without noting the tension between affirming political liberty and leaving any role for the difference principle. Alternatively, Rawls' statement that important issues are left to societal choice may embody not the view that political liberty is intrinsically valuable but merely the conclusion that democracy is the best available real world mechanism, the best method of "imperfect procedural justice,"ss for finding and implementing the laws and policies that his two principles of justice require. ${ }^{56}$ In this view, a right of people collectively to choose to promote particular values or notions of the good is not the reason that "the theory of justice alone" does not determine the choice between socialism and capitalism or the reason that the choice is left to legislative determination. ${ }^{67}$ The apparent indeterminacy of the principles of justice results not because the principles of justice do not control the choice. Rather, the indeterminacy-and, therefore, the need for "politic" decisions-is caused by either one or both of two other factors. First; the indeterminacy may exist because the consequences of the choice for the worst off depend on the specific culture, tradition, technology, and opportunities of a given real society. ${ }^{68}$ The choice, therefore; becomes determinate only after one integrates the principles with these chance empirical factors. Second, indeterminacy follows our limited knowledge of the consequences of implementing one or another societal structure; what justice requires may depend on unavailable information and uncertain predictions of the future. ${ }^{59}$ Thus, although abstract theory cannot by itself determine the choice of laws and structures, legislators should follow the dictates of the two principles of justice as applied to their best understanding of

Id. at $198-99,284,318,320$.

5 Id. at 85. Rawls emphasizes designing the political process to perform this instrumental role, id. at 229-30, but denies that this is the process' sole justification. Id. at 233-34. Reducing politics to such an instrumental role is common among liberal theories. See, e.g., B. ACKERMAN, supra note 10. It also provides a classic utilitarian justification for democracy.

J. RAWLS, supra note 9 , at $296,356$.

87 One must here carefully distinguish the "legislative stage" in Rawls' four-stage sequence, which is merely an expository device to determine what justice requires, $i d$. at $197 \mathrm{n} .2$, and the real legislature he imagines as part of an actual, just society which is discussed in the text here.

s. Id. at 274, 280-81; see supra note 47.

so J. RAWLS, supra note 9 , at $199,201,357$. But see id. at 362 (principles of justice may not always be clearly determinate). 
social facts. ${ }^{60}$ All that people can do is make informed, but debatable, guesses about what justice requires. The proper function of the political process is to make these guesses. ${ }^{61}$

This view of the political order concedes a place for human (instrumental or empirical) judgment, but not for value choices. It denies the value of political liberty as a right of people to choose what they and their world should be and instead treats the political order as a flawed, "second best" solution to the problem of finding and implementing theoretically correct results. Politics becomes not a value debate but an attempt to find which institutions best conform to the two, abstractly determined, principles. "[M]ajority rule is adopted as the most feasible way to realize certain ends antecedently defined by the principles of justice." ${ }^{\text {22 }}$ Presumably, one should replace both the legislature and majority rule if one finds that computers could better perform these basically technical tasks.

\section{b. The Choice Situation}

A more analytic objection to Rawls' theory results from an examination of his development of the reasoning within the choice situation. As Rawls construes the reasoning in the "original position," the choice of principles inevitably will be irrational. In fact, there could be an alternative institutional structure that would be unanimously preferred to the structure required by the chosen principles.

In the original position, the "veil of ignorance" allows the parties only limited knowledge of what goes into making up their "good"-namely, Rawls' list of primary goods. In these circumstances, Rawls, as well as many commentators, ${ }^{68}$ conclude that the dominant, rational objective for the "chooser," while in this original position, is to try to obtain a maximally secure amount, a maximum amount, or some combination of a secure and large amount of these goods. A person in the original position adopts this maximization orientation irrespective of the orientation's consequences for things other than primary goods that she will turn out to value in the real world.

If achieving a maximum amount of primary goods could have no negative consequences for obtaining or achieving other desired goods, focusing the choice exclusively on Rawls' limited list of primary goods

so See id. at $284,335,361$. "The legislative discussion must be conceived . . . as an attempt to find the best policy as defined by the principles of justice." Id. at 357.

"1 "Each rational legislator is to vote his opinion as to which laws and policies best conform to principles of justice." Id. at 361 .

es Id. at 361-62.

as See supra note 19. 
might not be objectionable. But the set of institutional arrangements that will maximize one type of good normally will affect the availability of other goods. For example, consider the quality of interpersonal relationships as one type of "good." Any structure of government and economic activity, including that which maximizes the wealth of the worst off, inevitably affects the society's patterns of interpersonal relations; the structure will affect both the costs of producing and the preferences for various "goods," including particular forms of interpersonal relations. Of course, a person might value highly those forms of interpersonal relations or other, "nonprimary" goods that are disfavored by those social institutions that maximize the possession of primary goods by the worst off. In this case, the person would find the maximization choice, the "difference principle," undesirable. And since anyone (indeed everyone) might value these disfavored goods, everyone, including the worst off, might be disadvantaged by the maximization. ${ }^{\text {of }}$

More formally, the problem of making a rational choice in Rawls' original position is that the choice, for example, to maximize primary good $A$ may have the consequence that nonprimary good $B$ will be chosen (more preferred or made cheaper) rather than nonprimary good $C$. In contrast, if $A$ were not maximized, the relative cost of producing $C$ would be less or the relative preference for $C$ would be greater. Thus, the choice of maximizing $A$ favors $B$ over $C$. While maximizing good $A$ may be rational if its maximization has no consequences for $B$ and $C$, given that it does have such consequences the rationality of the choice to maximize $A$ will depend on one's valuation of these other subsidiary goods. But by requiring the choice to be made under the veil of ignorance and to be limited to a discrete list of primary goods, Rawls excludes consideration of how the choice affects subsidiary goods $B$ and $C$. Thus, Rawls' original position denies the chooser sufficient information with which to know whether her choice, which consciously takes

- Like Rawls' design of the original position, my criticisms are designed to get where I want to go. My critique, that limited knowledge causes the choice of principles to be irrational, highlights a particular aspect of the problem of choice. I implicitiy assume that the content of the primary goods is sufficiently precise that one could, at least in theory, distinguish the contribution of different institutional structures to the production and distribution of these goods. In contrast, a critic could emphasize the lack of specificity of the content of primary goods in order to demonstrate that the choice of principles is fundamentally indeterminate until other values, which give the needed precision, are added. See, e.g., Hart, Rawls on Liberty and its Priority, 40 U. CHI. L. REV. 534, 546-47 (1973). In a sense both critiques make the same point-one cannot rationally know how much to value particular goods (particular liberties) outside the real world. Making the choice in the abstract, without knowledge of people's values, leads to irrational results while avoiding the choice leads to indeterminacy. The possible solution that permits reliance on real world information in the choice situation is discussed below under the heading, "Failure of Modifications," infra text accompanying notes 68-71. 
account of only the limited list of primary goods, is rational. ${ }^{\text {os }}$ An example may clarify this point. Suppose that the economic organization that provides the greatest wealth for the worst off group requires a hierarchical organization of authority in industry. Suppose further that this organization "produces" fewer friendship relations, more manipulation, a generally less egalitarian society, or a lesser sense of self-mastery and worker craft pride than would a less hierarchical system. If friendships or an egalitarian society are not included in Rawls' list of primary goods ${ }^{66}$ but are valued by individuals, including the poor, then the choice to maximize the wealth of the poor is not

es The basic structure of this argument is that the Rawlsian construct must either exclude information that is necessary in order for the choice to be rational or avoid the crucial choices until such information is available and, thereby, fail to provide a procedure for choosing useful, determinate principles. Many arguments critical of Rawls' theory have basically this structure. Consider, for example, the claim that the wisdom of the absolute priority of the maximum equal liberties principle over the difference principle should depend on knowledge of both the economic consequences of maximum equal liberties and the need or desire for increased material resources. Likewise, consider the recognition that maximum equal liberties does not have meaning until one can "add up" various liberties but the valuation will either be irrational if done abstractly, or will involve value choices and will favor particular people if based on real-world knowledge. See, e.g., Hart, supra note 64; see also Esthete, Contractarianism and the Scope of Justice, 85 ETHICS 38 (1974); Tribe, Policy Science: Analysis or Ideology?, 2 PHIL. \& PUB. AFF. 65 (1972).

The Rawlsian choice is arguably irrational in a second way, which utilitarians try, I think unsuccessfully, to exploit. Rawls relies on an analogy to the choice of a maximin rule in arriving at his two principles of justice. J. RAWLS, supra note 9, at 150-51. A maximin rule essentially dictates that one choose from alternative sets of possible outcomes that set which has the highest minimin possible outcome. Id. William Fellner notes that a choice of a maximin rule requires extreme assumptions about the nature of people's utility functions (that is, precise knowledge that people have extremely unusual utility functions) or an extreme disbelief (which is quite different than lack of knowledge) about the possibility of receiving more than the minimum payoff. $W$. FELLNER, PROBABILITY AND PROFIT 142 (1965) (relied upon in J. RAWLS, supra note 9, at 15456). In contrast, in Rawls' original position people simply have little knowledge about how much they will value different distributions (their utility functions) and have only the "vaguest knowledge of likelihoods." J. RAWLS, supra note 9, at 155. Thus, the extreme assumptions that would suggest the maximin rule do not characterize the original position. But see supra note 18. While Rawls chides the utilitarian for relying on doubtful, contingent assumptions in arguing for various principles, sec, e.g., id. at 159, the assumptions on which he relies are much more doubtful and, although pointing in the same direction as typical utilitarian assumptions, are much more extreme versions of these assumptions. Moreover, if, in the real world, Rawls' assumptions happened to be true, they would lead the utilitarian to implement something like his difference principle-except that some individuals could in principle and might in fact be left without anything. The utilitarian, however, has the advantage that the utility analysis is more sensitive to human needs and concerns in that it takes into account the degree to which people actually find outcomes unacceptable, rather than hypothesizing that gains beyond those provided by the difference principle are unimportant, id. at 154-56, and the utilitarian can, in theory, identify the point at which further gains matter little. Thus, utilitarianism takes into account the fears and hopes of people in the original position to the precise extent that real-world conditions make their fears and hopes relevant. These observations, however, do not show that a person in the original position should chose average utilitarianism. In addition to various other objections that Rawls rightly makes, average utilitarianism would involve the problem, mentioned infra text following note 71 , of sanctifying morally objectionable features of the status quo.

* The possibility that friendships, etc., are included and properly weighted within some category of primary goods, for example, are aspects of wealth, is considered below under the heading "Failure of Modifications," infra text accompanying notes 68-71. 
necessarily rational even for the worst off. Everyone, including the poor, might prefer an "economically" poorer but less hierarchical social order to the order required by Rawls' two principles. Moreover, even if, in the existing society, people, including the worst off, presently value increased wealth more than increased friendships or greater equality, if they have a right of self-determination they must have a right to choose institutional structures that will make preferences for equality or friendship more general and more intense and preferences for more wealth less intense. ${ }^{.7}$

In trying to construct a choice situation that prevents a person's actual, particular preferences, values, talents, and circumstances from distorting or biasing the reasoning process, Rawls' veil of ignorance eliminates information that is necessary in order rationally to choose principles for determining how society ought to be structured. Without more information, one cannot even know which principles will most advantage the worst off group. The worst off may prefer a little less of primary good $A$ if they can have more of nonprimary good $C$ rather than nonprimary good $B$.

\section{c. Failure of Modifications}

Either of two modifications in Rawls' structuring of the choice situation would avoid the irrationality discussed in the preceding section. First, one could treat all subsidiary goods, for example friendships and social or economic equality, as aspects of recognized primary goods. One's friendships and the satisfaction of a desire for an egalitarian society could count as aspects of one's wealth. Then the choice to maximize primary good $A$ would not blindly bias the choice between subsidiary goods $B$ and $C$ because $A$ would include both $B$ and $C$. Equivalently, the chooser in the original position could consider the possibility that people will desire various subsidiary goods and, therefore, could delay giving concrete meaning to the list of primary goods, wealth for example, until some point after the choice of principles in the original position (possibly until the constitutional and legislative stages in which Rawls partially lifts the veil of ignorance). Then, when institutional structures were chosen, people's receipt of various "subsidiary goods" could be treated as the receipt of an amount of wealth, the amount

67 See Gruenberg, The Happy Worker: An Analysis of Educational and Occupational Differences in Determination of Job Satisfaction, 86 AM. J. Soc. 247 (1980). Gruenberg argues that intrinsic rewards are more satisfying for all workers than are extrinsic rewards, and that there is no evidence that workers must learn to appreciate the intrinsic satisfaction of work. Workers apparently learn to like extrinsic rewards, learning which helps to reduce dissonance when intrinsic rewards are not available. 
determined (roughly) by the extent of actual people's existing preferences for the goods. The institutional structure that would maximize the wealth of the worst off could then be identified and chosen.

Second, a person choosing principles in the original position could be given complete information about all existing people's current and projected desires, including their desires for various subsidiary goods. ${ }^{68}$ The person would only be denied knowledge concerning which of these people she happened to be. Although this change in the veil of ignorance might change the choice of principles, if this information of the existing set of preferences were available the choice would not be irrational in the way criticized above.

In practice, both modifications give the decisionmaker the same increase in information. Both avoid or delay the choice that mandates particular societal structures until the decisionmaker knows how much people value specific forms of wealth or, in the second formulation, how much they value subsidiary, nonprimary goods. In this way, both methods avoid the irrationality of basing the choice on insufficient information.

Although changing the veil of ignorance to allow knowledge of people's conception of the good modifies Rawls' model, the modification may not seem important to his theory. One might think that the only purpose of the veil of ignorance is to prevent a person from choosing principles designed to favor her personal interests. ${ }^{68}$ The information that the proposed modification adds does not contradict this purpose. The person in this modified original position still does not have information about herself. She still must act as if she might turn out to be anyone. ${ }^{70}$ Therefore, one might conclude that this increase in information does not violate the requirements of equality.

This conclusion is wrong. The increase in information subverts ethically central features of Rawls' approach. Rawls, in common with other nonrelativistic moral theorists, aims to avoid making his theory of justice dependent on particular conceptions of the good. Using the existing society as the starting point means that people's existing views of the good determine the principles of right. At a philosophical level, reliance on these existing views of the good arguably contradicts Rawls'

\footnotetext{
es In his formulation of the veil of ignorance, Rawls excludes knowledge of "the particular circumstances of [the parties'] own society. That is, [knowledge of] its economic or political situation, or the level of civilization and culture it has been able to achieve." J. RAWLS, supra note 9, at 137. However, in his initial description of the veil of ignorance, only information about oneself is excluded. Id. at 12.
}

- See id. at 12.

70 But see supra note 18. 
view that "the concept of right is prior to that of the good."71 More important, by avoiding reliance on any particular conception of the good, Rawls avoids infecting his principles with morally objectionable conceptions of the good. His original position and veil of ignorance accomplish both objectives. In contrast, modifications such as those proposed above require reliance on some set of values or preferences with which to evaluate the importance of various "goods" ( $B$ and $C$ ) that implementation of possible principles of justice would affect. The proposed modifications use the existing society's values or preferences as the starting point from which to choose principles. This starting point, although an apparently natural one, seems morally arbitrary and, on reflection, can be expected to lead to morally objectionable results.

The arbitrariness seems obvious. People's conceptions of the good in an existing society have no greater moral legitimacy, merely because they presently exist, than those that will exist in some future society or that would exist in a future just society. Although one might assume that existing people's values or preferences are surely the ones that should control in "their" society, this assumption hardly suffices when the object of Rawls' enterprise is to obtain a standpoint and to choose principles of justice from which and with which to evaluate existing society. If any notions of the good are relevant for this evaluative enterprise, the relevant preferences or values should be those that people in a theoretical, just society would have.

The proposed modifications also undermine one of the most appealing aspects of Rawls' -original position methodology-namely, its (supposed) capacity to allow us to step outside our real-world position and to reason about principles of justice without being influenced by our existing, unjust prejudices. Few will deny that injustice, in particular unjust domination of some by others, exists in our society as it has in all societies throughout history. All societal structures, including unjust ones, will influence people's values and perceptions. Some of our existing preferences and values will inevitably reflect and to some extent embody values that rationalize or are otherwise distorted by existing unjust structures of domination and inequality. These distortions will infect the preferences and the perceptions of both supporters and critics of the existing order. The ethical appeal of the judgments formed in Rawls' original position depends on their not reflecting any of these existing forms of domination. One cannot make this claim for judgments based on existing notions of the good. Principles of justice chosen

71 J. RAWLS, supra note 9, at 31. "If a knowledge of particulars is allowed, then the outcome is biased by arbitrary contingencies." Id. at 141. See also id. at 253-56. 
on the basis of existing notions of the good would sanctify objectionable features of the status quo. In doing so, the principles would lose their claim to moral legitimacy.

\section{d. Summary}

This examination of Rawls' analysis reveals a serious dilemma. If accepted without modification, his framework makes the choice process irrational. Rawls' exclusion, in the original position, of information about the existing society apparently leads to a choice of two principles for determining social structures that rules out structures that everyone, including the worst off, might prefer to those structures that do conform to the two principles. In this sense the exclusion leads to irrational choice. If modified to allow reliance on the information needed to avoid this irrationality, the model becomes morally arbitrary and, more important, morally perverse by preserving morally objectionable features of the status quo. Some critics might conclude that these problems so completely undermine Rawls' efforts that one should immediately abandon his approach. Nevertheless, I will try to describe a successful resolution of these problems within Rawls' framework of respecting people as equals and show that this resolution results in what I call the equality of respect model of equal protection.

\section{The Equality of Respect Model}

\section{A. The Theoretical Response to Rawls}

The equality of respect interpretation of equal protection consists of three principles. First, the state must recognize the fundamental nature of people's right to participate in a political process that chooses and attempts to implement the group's conception of the good society-a political participation principle. Second, the state must not pursue purposes, and the political process must not further individuals' preferences, to subordinate or to denigrate the inherent worth of any category of citizens. Third, the state must guarantee to everyone those resources and opportunities that the existing community treats as necessary for full life and participation in that community. ${ }^{72}$ In this section I

72 Michael Walzer's impressive discussion of spheres of justice, published after this Article was written, is rich in its implications for constitutional law. M. WALZER, SPHERES OF JUSTICE (1983). Despite the conflict between our methodologies, my conclusions in this paper closely parallel some of these reached by Walzer. Although Walzer is antagonistic to the Rawlsian approach that I rely upon, see id. at 4-5, 79, 260-61,267, and although I object to his explicit relativism and to his claim to appeal solely to social meanings, id. at $29,313-14$ (but consider his recognition of the propriety of advocating new meanings and of the possibility of class conflict among meanings, 
will argue that these three principles are among those $\mathrm{e}^{73}$ that people in Rawls' original position could most plausibly and rationally choose. ${ }^{74}$ In the next, I will develop some of the doctrinal implications of these principles.

\section{The Political Participation Principle}

If a choice made under Rawls' veil of ignorance to maximize particular goals is irrational, and if the choice of goals for society made with fuller information of existing people's preferences and values is

id. at 314)-a methodology which apparently repudiates any any critical interests in interpretation and understanding but to which I expect he is not and could not be faithful even in his own analysis-the similarity of certain of our conclusions is striking.

Walzer emphasizes the importance of my first principle: a political participation right, although he apparently thinks that the principle must lack universal justification or universal applicability. Id. at $61,277-78$. In addition, he agrees with my claim that this principle requires a formal equality of political rights and the one-person/one-vote rule, not an equality of power or influence. Id. at 304-06, 309; cf. Baker, supra note 1, at 1072-84. Walzer not only argues for what I call the just wants principle and, more specifically, for the notion that culture and politics determine the content of just wants, M. WALZER, supra, at 84; see also id. at $65,75,78-79,91$, but he also emphasizes, as I do, the objectionableness of trying philosophically (abstractly) to define determinative distributive principles in a way that eliminates political choice. Id. at 67 \& n.*. Finally, although he does not focus on the issue, it seems clear from his critique of segregation in housing and education in America, id. at 221-26, his rejection of a system of "guest workers," id. at 56-61, and his notion of the relationship of self-respect to membership, id. at 278 , that he accepts the "no subordinating purpose" principle.

Moreover, Walzer at times appears to be adopting a two-tier theory in which some issues are clearly subject to cultural and political determination (although this may not be true for a guarantee of minimal amounts of food, id. at 79) and other issues are determined more abstractly or philosophically (even if only on the basis of a deep level of the social meaning of being a person who is part of a group). Cf. L. WITTGENSTEIN, ON CERTAINTY \$\$ 98-99, at 15 (G. Anscombe \& G. von Wright eds. 1969). This two-tier theory, which parallels what I have argued for in this Article, seems implied by combining several of his remarks. For example, he claims that objectionable domination and tyranny result from violating the distributive principles internal to the social understanding of particular types of goods. He also "observes" that "need" has been the proper distributive principle for some, although different, goods in all political communities, M. WALzER, supra, at $68,79,84$, and asserts that once the community has undertaken to provide for a need, it "must" provide for it in proportion to member's needs, id. at 75.

${ }^{78}$ I would argue that people in Rawls' original position would also adopt a liberty theory of the first amendment as a basic principle of justice. This first amendment theory is more precise than and probably not exactly equivalent to Rawls' first principle, equal maximum liberty. See Baker, Counting Preferences, supra note 42; Baker, Scope of the First Amendment Freedom of Speech, 25 UCLA L. REV. 964 (1978) [hereinafter cited as Baker, Scope of the First Amendment].

${ }^{74}$ Although the argument only claims that people could rationally choose these three principles, this inconclusiveness should not be troubling. Given, as I assume, that Rawls' formulation of the original position embodies proper principles of moral equality, as long as the choice of these three principles is more plausible or rational than any other choice suggested, the argument that they ought to be accepted should be persuasive. If other, consistent principles seem equally rational-for example, principles protecting first amendment liberties, see supra note 73-the argument for them would merely provide a more complete description of a just structure. If other, inconsistent principles seem equally rational then, as far as the present development of the analysis is concerned, implementation of either set would be equally just. In other words, the analysis would suggest that either there are alternative sets of just, organizing principles, or our moral analysis is merely incomplete at present. 
arbitrary given the arbitrary nature of these preferences and is objectionable because the choice perpetuates existing forms of domination, one must consider whether these problems are a necessary aspect of choice within a Rawlsian original position or whether these problems result from the particular way Rawls approached the choice of principles.

Some critics, adopting Rawls' own description of the reasoning process in the original position, conclude that people in this abstract, ahistorical context can choose only distributive principles designed to divide up goods. Accordingly, the choice situation must result in "end state" principles requiring particular types of distribution. ${ }^{75}$ This conclusion does not follow. On the contrary, people seeking to realize their own conception of the good behind the veil of ignorance might reject end state principles in favor of at least partially process oriented principles. The analysis in the last section argued that, if people were rational, they would not choose to promote a particular distribution of primary goods if that choice would result in unconsidered consequences concerning various nonprimary, subsidiary goods. Of course, any principle or decision rule that has real-world implications will favor some goods or distributions over others. The unforeseen and unconsidered favoritism loses its irrationality, however, if after reflection, people chose the principle that led to the unforeseen favoritism precisely because they agree that the results which that principle favors would be acceptable. ${ }^{76}$ This reasoning, for example, provides the basis for typical defenses of the policies of democracies. Within some particular historical conditions, majority rule, as compared to some specified elitist system, might favor either environmental protection or resource exploitation. The democrats would assert, however, that this unforeseen favoritism is acceptable precisely because the favoritism is a consequence of their chosen principle, ${ }^{77}$ majority rule-a process argument that does not apply to the unforeseen favoritism for some nonprimary goods that results from Rawls' difference principle. Of course, the democrats are persuasive only if the democracy on which they rely is itself

7s See supra note 19. Nozick argues that, behind a veil of ignorance, people would choose an end-state principle for the distribution of classroom grades. R. Nozick, supra note 19 at 199-201. In fact, his mistake here illuminates a more general problem with his claim. Nozick improperly treats grades like money - as valuable only instrumentally and competitively. Given that people had information about various useful social functions grades potentially could serve, functions including information feedback, one would expect them to choose a performance related (historical) principle of distribution if grades were to exist. The question that they would not have enough information to answer is whether grades as an institution ought to exist- - for example, do grades work to the advantage of the worst off?

${ }_{70}$ See supra notes 57-62 and accompanying text.

77 See J. RAWLS, supra note 9, at 85 (description of pure procedural justice). 
acceptable-which may not always be the case. In fact, democracy quite clearly involves the problem mentioned earlier of allowing choices that reflect and embody preferences that result from unjust structures of domination. ${ }^{78}$ Nevertheless, people in the original position can reason about whether they would, and about the conditions under which they would, find acceptable democracy's inevitable favoritism for some goods or some conceptions of the good. If democracy is desirable but desirable only under certain conditions, they could then choose additional principles that embody those conditions.

The choice of a political participation principle stems from the recognition of two considerations. First, people in the original position should try to avoid the irrationality that results if they decide, without information concerning people's notions of the good, how primary goods should be distributed or, more generally, how major social institutions should be structured. People's concern to avoid this irrationality gives them an interest in having some voice in making the inevitable choices to adopt or create (or, in practice, to maintain or change) those structures that will affect the distribution of both "subsidiary" and primary goods. Moreover, given that in the original position the only way to protect one's own right to have a say in real-world politics is to protect everyone's right, they should decide that everyone should have an equal right to participate as an actual, concrete person in the inevitable collective decisions concerning structures that favor or disfavor various goods-and in all other collective choices that constitute the framework of social life or that influence what one will be. Although this right to participate favors some structures or goods over others, it does not operate independently of people's actual preferences and values. The choice of preserving for everyone an equal right to participate means that a necessary condition for $B$ to be preferred is that intervening decisions of actual people on balance favored $B$. Thus, this political participation principle avoids the irrationality of mandating a maximization of primary good $A$ with a resulting favoritism for subsidiary good $B$ over $C$ in a context in which one cannot know whether people actually value the added amount of $A$ and $B$ more than they value the lost $C$.

Second, even in the original position, people could recognize that an important good might be not merely getting as much as possible of what they desire (this is accomplished by avoiding irrationality as discussed above) but also being able to choose or determine the type of people they will become-to engage in attempts at self-determination. 
In other words, people could recognize that the right of political participation might turn out to be an intrinsically and not merely instrumentally important good-a prime "primary good." Moreover, choosing in the original position this "participatory" right avoids our first, intuitive objection to Rawls' solution, that his principles eliminate the "political" realm. Still, the problem of sanctifying morally objectionable aspects of the status quo remains.

\section{The No Subordinating Purpose and Just Wants Requirements}

Agreement on the first principle, an entitlement to be involved in collective decisionmaking, will not end the predictable dialogue in the original position. A person who does not know who she will turn out to be would probably be especially concerned about the condition of the worst off and of those who lose out politically. This observation led Rawls to argue that people would choose his difference principle. Although the difference principle's mandate of particular outcomes was shown above to be unacceptably irrational, ${ }^{79}$ Rawls seems persuasive in concluding that people in the original position would be concerned to avoid unbearable or unacceptable life prospects. One could especially expect people in the original position to agree on principles that respond to this concern if the principles do not lead to the objections leveled against the difference principle.

The second two principles of the equality of respect model meet these criteria. I will argue that one could expect people in the original position to agree on a second principle, a prohibition on political decisionmakers adopting a purpose to subordinate or denigrate anyone, and on a third principle, a requirement that society bear the responsibility of ensuring that all people, in particular those whom some democratically chosen societal structures might leave emptyhanded, receive those resources and opportunities that the society treats as necessary for meaningful life and full participation in the community. ${ }^{80}$ These constraints, of course, need greater elaboration. The second principle leaves the meaning of "purpose" and the notion of "subordinate or denigrate" unspecified. The third principle, the just wants guarantee, leaves open the question of what counts as evidence that society treats certain items as "necessary for full participation," and what circumstances suffice to

72 See supra text accompanying notes 63-67.

so Choice in the original position might place other restrictions or demands on political choice, but development of this point is unnecessary for understanding equal protection. In particular, one could argue that the political process must respect people's autonomy. This would require "constitutional" protection of liberty. See supra note 73. 
make basic resources and opportunities adequately available. ${ }^{81}$ For example, can society decide that, except possibly during brief emergencies and except for the severely handicapped, generally available economic opportunities provide adequately for people's needs for food and shelter? Does that make as much sense in the modern economy as it did under the conditions of frontier society? Before further elaborating these principles, more explanation of why they would be chosen is needed.

As Rawls recognized, one cannot demonstrate, but at best can only make plausible arguments, that rational people in the original position would or should choose particular principles. The choice of these two substantive limitations on the political process, however, are very plausible. Specifically these limitations respond both to the main objections leveled against Rawls' principles and to the main consideration supporting his difference principle.

The two objections to Rawls' principles were that they would irrationally dictate the content of the social structure, and that they would eliminate the important self-determinative realm of politics. These objections are unconvincing as applied to a prohibition on subordinating purposes and to a guarantee of the availability of those "goods" that the community treats as essential for a full and decent life and for full participation in the affairs of the community. Although implementing these two principles (or any other structural principles, including the democratic participation principle itself) will both influence the content of the social structure and limit the political realm to some degree, ${ }^{82}$

s1 Generally, one might interpret constitutional provisions, widespread legislative action, and other societal practices that attempt to avoid or modify reliance on the market as evidence of a societal view that members of the community cannot be expected to do without a particular good or opportunity. See San Antonio Indep. School Dist. v. Rodriguez, 411 U.S. 1, 110-17 (1973) (Marshall, J., joined by Douglas, J., dissenting); see also M. WALZER, supra note 22, at 64-94; Michelman, Process and Property in Constitutional Theory, 30 CLEV. ST. L. REV. 577, 588-89 (1981).

ss The democratic participation principle limits the political sphere's authority to arrange the political sphere in order to promote permissible goals. In contrast, following Justice Stone and Professor Ely's argument that the Court should not impose distributions that implement normative values, some dissenting justices argued in the one-person/one-vote cases that as long as the majority had ultimate control, that majority should be allowed to design the representation system in order to promote particular policies-for example, rural control of county government with its predictable consequences for the expenditure of county revenue-and to protect particular minorities. See Avery v. Midland County, 390 U.S. 474, 488-89 (1968) (Harlan, J., dissenting); id. at 508 (Fortas, J., dissenting); see also WMCA, Inc. v. Lomenzo, 377 U.S. 633, 744-65 (1964) (Stewart, J., joined by Clark, J., dissenting); Lucas v. Colorado Gen. Assembly, 377, U.S. 713, 741-43 (1964) (Clark, J., dissenting). Although many different political forms would be consistent with the political participation principle as described here, both that principle and the Court rule out these violations of the one-person/one-vote principle. See generally Baker, supra note 1, at 1072-84. Likewise, H.L.A. Hart notes that the idea of legally unlimited sovereignty does not avoid limits. This is obvious when one observes that the concept of unlimited sovereignty has been given two interpretations, one of "self-embracing omnipotence" and one of "continuing omnipotence," 
unlike Rawls' difference principle these principles pose no danger of totally dictating the content of the social structure or of eliminating politics. Moreover, their effect on the social structure is neither irrational nor ethically objectionable if people from an ethically defensible perspective, i.e., Rawls' original position, would desire or choose these effects. From the perspective of Rawls' original position, there are several reasons to expect that people would seek these limitations.

As noted, even the worst off might object to a requirement that the structure of society maximize their wealth. Such a requirement bars the choice of alternative structures that better advance other values that the worst off might have. This conclusion is reinforced if the difference principle turns out to be unnecessary to prevent them from being unacceptably impoverished. ${ }^{83}$ The worst off, however, would have no reason to preserve for society the option of choosing to subordinate the worst off. Although one might concede that some of one's interests ought to be sacrificed for the general good, conceding the acceptability of being "picked on" is a different story. A person who knows nothing about how to value various "goods" would not be able rationally to make a choice among outcome principles that either favor or disfavor these goods. In contrast, there are no persuasive reasons-and from the perspective of a moral system that treats people as equals and certainly from the perspective of the worst off, no reasons at all-to maintain the option of choosing to subordinate or denigrate a portion of the community. In a sense, Rawls recognized this point. By requiring that in choosing basic principles in the original position people have no concern about the welfare of others, that is, be mutually disinterested, Rawls eliminated the effect of envy as well as the effect of more beneficent sentiments on the choice of principles. As a stipulation, this constraint seems problematic. ${ }^{84}$ In contrast, Rawls' more specific arguments that envy is collectively disadvantageous ${ }^{85}$ should make sense within the original position and could properly be embodied in the principles chosen there. ${ }^{86}$ The no subordinating purposes principle sim-

that differ in their view of whether the sovereign can bind itself to act or not in particular ways in the future. H.L.A. HART, THE CONCEPT OF LAW 70-72, 145-46 (1961). The different interpretations merely imply different limits on the political sphere.

ss See infra text accompanying notes 89-90.

at The requirement arguably biases the analysis toward emphasizing individualistic, possessible primary goods and away from the possibility that people would prefer or even value goods of a more interpersonal nature. Baker, Counting Preferences, supra note 42.

${ }^{83} \mathrm{~J}$. RAWLS, supra note 9, at 530-34 (envy and spitefulness are to everyone's detriment).

s6 Although the veil of ignorance would properly rule out specific knowledge of both the chooser's beneficent as well as her envious or subordinating sentiments, an argument in the original position for prohibiting reliance on beneficent sentiments in real-life politics does not follow the way the argument against envy or, more persuasively, against subordinating purposes follows. This observation suggests that claims about the proper role in politics of preferences for others is a 
ply generalizes this point.

In addition to not being irrational, the principle that holds certain purposes or objectives to be impermissible bases for political decisions does not eliminate but, in a sense, purifies politics. This limitation identifies politics with the activity of people choosing and creating the nature of their community while respecting each other's equality of worth and autonomy. Choices with a purpose to subordinate or denigrate some portion of the community are barred as inconsistent with the vision of politics that assumes respect for all.

The underlying reason for the expository power of Rawls' original position methodology is that it seems to embody the notion of respecting people's equality of worth. From this fundamental notion one derives the right to participate in political choice. Any restriction on the democratic process that also embodies this fundamental notion of respecting people's equality of worth is equally justifiable. The most obvious such restriction is a prohibition on government action whose meaning or purpose is to show disrespect or to deny people's equality by subordinating them. Although different democratic processes and various outputs are permissible, those chosen should be consistent with respecting people's equality of worth. Thus, the process must allow popular participation but must exclude reliance on preferences to subordinate or denigrate. And the output must not embody or represent a purpose to denigrate or subordinate. Thus, the original position methodology indicates how the same fundamental value leads both to the right to participate and to this important limitation on that democratic right.

Some critics will argue that the focus on impermissible purposes is too narrow. In the original position, people might rationally decide to ban political choices that have subordinating effects. This decision, however, would return us to an end result approach. An effects approach that defines the prohibited subordination as "reducing the prospects of some in a way that benefits other, better situated people" basically returns us to Rawls' difference principle. Then all the objections to the Rawlsian version of the outcome equality model would apply to this principle. Moreover, the prohibition on subordinating purposes, when combined with the third requirement, that the community make available to everyone the goods and opportunities the community considers necessary for meaningful life and full participation, substantially reduces the need to fear subordinating effects.

The equality of respect model's just wants guarantee also restricts 
but certainly does not eliminate politics; nor does it reduce politics to an instrumental search for means. Rather, the guarantee only prohibits certain community choices-those that leave some people without the prerequisites for full and meaningful life. It leaves other choices, and even the responsibility to determine what amounts to these "prerequisites," to collective decision. ${ }^{87}$ By making clear the community's obligation to guarantee to all the opportunity for full life as understood by that community, this requirement establishes people's collective, political responsibility to define full and meaningful life and to give content to this egalitarian principle. ${ }^{88}$

The contribution of the just wants guarantee to protecting against unacceptable outcomes provides a central argument for its adoption. Rawls' primary rationale for the choice of the difference principle in the original position was to avoid outcomes that the chooser would turn out not to be able to accept ${ }^{89}$ - specifically, not having sufficient resources to lead a tolerably or acceptably meaningful life in the community. Rawls is persuasive that people in the original position, people who view themselves and others as equals, would want to avoid this danger. His difference principle, however, is a blunt, indiscriminate tool with which to respond to this danger. First, one cannot expect the difference principle to identify the precise line of unacceptable outcomes-which predictably will be a different point for different people. ${ }^{90}$ Moreover, the lower total wealth produced in a structure that conforms to the difference principle rather than utilitarian principles will prevent the realization of some preferences that some people, for example those with expensive tastes (or values), hold dear. Thus, in practice, the difference principle will be an unnecessarily high guarantee for some, and an inadequately low guarantee for others. The group with expensive tastes or life plans, might have unacceptable outcomes forced on them by the difference principle, unacceptable outcomes that

87 See supra note 81; infra text accompanying notes 163-65; infra text accompanying notes 142-60 (discussion of section five legislation); see also Duncan v. Louisiana, 391 U.S. 145, 149 n.14 (1968).

${ }_{88}$ This responsibility provides the most convincing explanation of Justice Brennan's interpretation of Congress's section five powers. See infra text accompanying notes 142-60.

so Moreover, Rawls suggests that people may have little reason to expect to do better than the difference principle.

90 See B. AGKERMAN, supra note 10, at 49-66. Ackerman recognizes that an equal distribution may lead to the frustration of some people's life plans, the mountaineer or the cathedral builder, while leaving the needs of others over-fulfilled. Ackerman, nevertheless, rejects equal fulfilment and adopts an equal distribution standard. This choice of standards is, however, not neutral. For one whose life plan is more expensive to receive more wealth does not require or even suggest a claim that she or her plan is intrinsically superior but only, first, that it is intrinsically expensive and, second, that fulfillment of life plans, not receipt of money, is the basic standard or measuring rod of the treatment or consideration that a person receives. But cf. id. at 52. The choice of a standard clearly involves a value choice that cannot be made "neutrally." 
a more utilitarian standard would avoid. In fact, any principle will result in outcomes that some people with particular needs or obsessions will find unacceptable. One cannot know abstractly (for example, in the original position) whether the difference principle or the utilitarian standard or a just wants provision will avoid the most unacceptable outcomes. Second, the bluntness of the difference principle causes possibly unnecessary frustration of people's desires. In order to do as much as possible to avoid intolerable eventualities, the difference principle sacrifices the collective power to promote various community goods, goods which even the worst off may prefer to the greater wealth provided by the difference principle.

In contrast to the bluntness of Rawls' difference principle, the just wants guarantee looks precisely to when a person does not have the goods or opportunities that people in that person's community consider basic. In those situations, failure of the community to provide these goods or opportunities would amount to sacrificing some people's meaningful life, as understood by others in their community, to the interests of other, better off members of the community. Society's responsibility may be met, however, if it prevents deprivations that people in that society generally find unacceptable.

Although the just wants guarantee may be a more precise technique than the difference principle for avoiding unacceptable outcomes, a person in the original position might argue that no one should be forced to do without what she personally considers necessary. In other words, a variable, individually defined rather than socially defined just wants guarantee would appear to provide even more precise protection. Nevertheless, in addition to being virtually unusable as a principle of structural evaluation, such an individualist focus may be less justifiable theoretically. First, the favoritism it gives to the person with the greatest (most expensive) needs may not, particularly in a world where no sharp line distinguishes "needs" from possible degrees of further selfrealization, be fair to those with lesser needs. Given scarcity and the inevitable conflict in the claims on resources, such a standard may not be capable of being fulfilled and, if it is, may unfairly deprive those with lesser needs of important opportunities and unduly deprive the collective of the political right of self-creation, a collective right that might even be exercised to provide for those individually defined needs that would not be fulfilled merely on the basis of the just wants principle. Second, given that the individualist focus might outstrip the available resources and, thereby, still leave some without their needs met, the socially defined just wants guarantee may provide the greatest protection against unacceptable results. 
The collectively defined just wants guarantee means that the society does not foreclose to anyone meaningful life and full participation as it understands these notions. In this sense, society exhibits disrespect or lack of concern for no one. In contrast, given the collective's own standards, failure to provide the just wants guarantee should be interpreted as consciously, purposefully sacrificing individuals in the pursuit of other collective, group, class, or individual values. Thus, in contrast to utilitarianism, to the difference principle, and to an individually subjective just wants principle, the collectively defined just wants guarantee appears as a rational, relatively fine-tuned response to the fear of unacceptable outcomes, the fear which Rawls identifies as a strong motivating force in the original position. As such, unlike outcome equality principles that eliminate politics, the just wants guarantee may be a prerequisite for making both democracy and the various choices of the political process legitimate as well as a partial embodiment of these democratic choices.

\section{The Necessary Incompleteness of the Model}

Two questions, which raised alternative dilemmas for Rawls' analysis, remain to be asked about the equality of respect interpretation: Do the three principles of the equality of respect model avoid embodying existing forms of domination in the process of choosing societal structures? Do they provide principles of justice sufficiently concrete both to inform our moral intuitions and to measure the justness of a society?

The first question stems from the objection that according practical scope to preferences that reflect the influence of structures of domination and injustice fails to respect people's equality. Since both existing structures and the legacies of past structures of domination affect existing people's notions of both the good and the right, our ability fully to recognize distorted preferences and structures of domination apparently depends on first escaping domination. For example, our ability to identify and our will to avoid various forms of racism or sexism directly correspond to our progress in eliminating them. A dilemma exists. Although the theoretical and practical objective must be to describe and provide an institutional structure and a politics that avoid all influence of structures of unjust domination, we cannot know fully what is necessary in order to escape domination without already having escaped. Rawls' original position offered a solution. Rawls insightfully required that society's basic constitutive decisions correspond to those that would be made in a hypothetical original position in which people were equal and in which the decisionmakers were under a veil of ignorance 
designed to eliminate the influence of preferences that reflect existing domination. But his solution was flawed. Excluding all information concerning actual, existing preferences while choosing principles that would determine the society's institutional structures led to irrationality. ${ }^{\text {11 }}$

Rawls' failure strongly suggests that the dilemma is not totally solvable. The equality of respect model avoids irrationality but only by permitting people to participate in establishing and changing the structure and goals of the social order on the basis of full information about their view of the good. Thus, the model allows choices that are warped by existing domination. Nevertheless, any method of choosing societal structures that provides enough information to avoid irrationality must provide too much to escape the influences of the existing order. No method will allow us to stand firmly outside the existing order to plan our escape; the best we can do may be to make reasoned choices with the knowledge we have.

This flaw in the equality of respect model may not, however, be fatal given the key redeeming functions served by the model's second and third principles. These principles or constraints, institutionally enforced as constitutional mandates, limit political actors' permissible reliance on existing preferences. Specifically, they limit reliance on precisely those preferences that presently most clearly can be seen to be unjust. Although these constraints may not be adequate to avoid all influence of unjust structures of domination, their implementation forces the political process to treat people as equals more than mere reliance on existing preferences would dictate. Thus, these constraints partially cure the problem of relying on existing values and preferences.

More interestingly, implementing the model's second and third principles has dynamic consequences. As collective decisions continue to either conform to the constraints or be rejected as unconstitutional, the political process continually creates new societal conditions. Conforming to these constraints at "time one" produces more egalitarian or more just structures at "time two" than would have resulted if the political process had embodied the rejected preferences. The consequence of rejecting these preferences and conforming to the constraints is to cause the resulting new environment and the corresponding new preferences and values to be somewhat less reflective of domination and inequality than before and, thus, to be an increasingly accurate expression of people's interactions and agreements as equals. Then these "better," new preferences influence political choices at "time two."

${ }^{21}$ See supra text accompanying notes 63-67. 
The process can be envisioned as a spiral. ${ }^{92}$ By forcing politics to go beyond existing conditions of domination, the constraints operate as the lever that raises the cycle of societal change into a spiral of increasing equality and decreasing domination. As the constraints help produce practices and institutions that increasingly recognize people's basic equality as moral beings (this equality being Rawls' central value and the value he tried to embody in the original position), we develop an increasingly reliable basis for trusting our judgments concerning which collective choices and social institutions are just and whether the collective decisionmaking process correctly represents choice under conditions of nondomination. Although twin but contradictory needs, the need to ground decisions in the real world if we are to avoid irrationality and the need to escape the real world if we are to avoid the distortions of inequality, necessarily prevent any complete or precise formulation of principles of justice, the equality of respect model provides a method of advance toward both a better understanding and a better realization of justice and equality. This is the most one can hope for given the limits imposed by our inevitably being located within history.

For the same reasons that the equality of respect model's three principles do not completely escape the influence of existing forms of domination, they also must fail to meet fully the second problem posed above: They cannot provide comprehensive guidance for our moral intuitions. They do, however, provide some guidance. The principles place important constraints on the political process and on political or normative reasoning. The equality of respect model excludes certain purposes and directs our attention to society's responsibility to guarantee the goods and opportunities needed for full life and participation. Both directives, however, become indeterminate at some point. For example, the second directive must be understood in light of the collective's right and responsibility to establish its own conception of what is necessary for full and meaningful life in its world. Still, the equality of respect model does require the guarantee of these goods and opportunities. Furthermore, this principle specifies a central issue or focus for the collective political debate: Given our egalitarian responsibilities and our natural, social, and technological environment, first, what ought we conceive to be necessary for full life within our society; and, second, do various desired aspects of collective life really require and justify the

93 See R. UNGER, supra note 14. Much of the critique of Rawls' theory of justice takes a form suggested by Roberto Unger. The equality of respect model, although not so obviously suggested by Unger-possibly even inconsistent with his critique of "legal" solutions to liberal problems - can be interpreted as an attempt to describe one institutional embodiment of the factors needed to create the spiral sought by Unger. First amendment rights arguably perform a similar function. Baker, Scope of the First Amendment, supra note 73, at 1024-28. 
cost of inequality that they impose? Of course, these are self-definitional-that is, political-questions, but at least the equality of respect model helps bring these questions into focus. Moreover, despite providing some guidance, the incompleteness of the model is inevitable. Any attempt to find clear and constant (timeless) conclusive principles is futile. This follows, first, if the basic principles of justice and of the structure of a just society must be at least partially open to human choice; and second, if, as suggested above, our moral judgment is an evolving but necessarily incomplete, developing capacity. Given these assumptions, we can never be in a position to capture justice with timeless principles.

Thus, the equality of respect model escapes the theoretical vacuousness of the neutrality model of equal protection and the irrationality of the Rawlsian outcome equality model. Although it fails to meet Rawls' goal of providing criteria adequate to judge the justness of a society, this failure is a comprehensible and an inevitable result of the historical dialectic. And the equality of respect model does provide principles that instruct us in how to constitute political practice while moving toward a progressively more just and egalitarian society.

\section{B. Equality of Respect and Equal Protection Doctrine}

The critique of the Rawlsian model led to an equality of respect model consisting of three parts: (1) the political participation principle, (2) the no subordinating or disparaging purpose restriction, and (3) the just wants guarantee. This section will begin to give these principles greater content, first by briefly examining two controversial, confused areas of equal protection doctrine and then by discussing more general doctrinal implications and limitations of the equality of respect model. ${ }^{\text {s3 }}$

\section{Impermissible Purpose}

Although the Supreme Court sometimes does not appear to distinguish purpose and motive $e^{94}$ and, at other times, treats subjective motive as the relevant concern, ${ }^{85}$ increasingly the case law makes clear that the

os In an earlier article, this task was undertaken with respect to sex discrimination, voting rights, and, to a lesser extent, impermissible purposes. In those contexts, existing case law was inconsistent with popular versions of process, rationality, or outcome approaches but provided clear support as well as detail to the equality of respect model. Baker, supra note 1, at 1070-96.

of See, e.g., Arlington Heights v. Metropolitan Hous. Corp., 429 U.S. 252, 265 (1977) ("Rarely can it be said that a legislature . . . made a decision motivated solely by a single concern, or even that a particular purpose was the 'dominant' or 'primary' one." "Proof of racially discriminatory intent or purpose is required ....").

${ }^{\text {os }}$ See, e.g., id. at 266 ("Determining whether invidious discriminatory purpose was a motivating factor ...."). 
crucial equal protection inquiry involves something more objective than the mental state of the legislator. The words "intent," "motive," "purpose," "meaning," and "function" suggest a rough continuum that moves from "subjective purpose" and an emphasis on mental states to "objective purpose" and an emphasis on social context. (Unless otherwise indicated, I will use "objective purpose," "contextual purpose," and "meaning" interchangeably.) From the perspective of this continuum, the Court's search for impermissible purpose usually relates to the objective-purpose or social-context end. The Court's interpretative inquiry looks to a social context in which we understand human actions and artifacts; the inquiry determines the purpose of the law or act on the basis of socially understood contextual factors and human practices. Nevertheless, one might still wonder whether the Court treats the contextual purpose or meaning of the government act as merely permissible and often sufficient evidence of subjective motives or whether contextual purpose is itself the relevant concern.

The last section relied upon the Rawlsian original position to derive the equality of respect principle of no subordinating purpose. The Rawlsian original position also provides some basis for determining what type of "purpose" should be central to the constitutional inquiry. The underlying objective of the equality of respect model's prohibition on impermissible purposes is to allow for political choice while both purifying the decisionmaking process and vetoing specific objectionable decisions. Neither the rationale for preserving politics nor the recognition of our inability abstractly to know the structure of the good or just society implies that "good subjective motives" of political actors ${ }^{88}$ suffice to legitimate choices that the given culture understands to disparage or subordinate some people. From the perspective of the original position, denying any political role to subordinating or denigrating preferences (subjective motives) of political actors significantly decreases the chances of unacceptable outcomes while allowing for collective efforts to promote positive conceptions of the good. These same considerations justify banning practices whose objective purpose or social meaning is to subordinate or denigrate some people. These practices create high risks of unacceptable outcomes. In fact, often, the practices are understood as

* If the prohibition on impermissible purposes is limited to "subjective motives," then in addition to all the traditional problems of identifying whose intentions count and how these intentions are discovered, one must determine how to treat unconscious motives. Possibly, the answer depends on whether we are more concerned with a moral evaluation of the actor or with an underlying functional understanding of the action. Presumably, the objectionable aspect of the action, but not of the actor, is the same whether or not the actor is conscious of her motives. This issue is eliminated by focusing on the meaning or purpose of the action without, however, turning the inquiry into a positivist effects analysis. 
having subordinating or denigrating purposes mainly because they create high risks of outcomes that the given society views as both avoidable and unacceptable. Moreover, from the perspective of that society, practices having such denigrating purposes are usually unnecessary aspects of, and are at best failed attempts at, a politics that constitutes and expresses a particular vision of the humanity and community of equal beings.

Of course, an objective or contextual purpose analysis would seem both irrelevant and somewhat mysterious to a methodological individualist, that is, to one who analytically reduces all collective wholes into their individual parts. ${ }^{97}$ The ubiquity of the tendency to see the world from this perspective may partially explain why most lawyers and legal theorists assume that the real concern in the motive/purpose inquiry must be with individual subjective motives-even though they grant that contextual evidence will suffice legally to prove the subjective motive. Nevertheless, this view of understanding the meaning or purpose of a text, a law, in terms of individual motive is routinely rejected by modern philosophers and hermeneutic theorists. ${ }^{98}$

Despite problems raised by some hermeneutic theorists, ${ }^{89} \mathrm{I}$ would think that the attempt to uncover subjective motives makes sense for certain inquiries-it would be useful for the biographer or the psychiatrist. Generally, however, the relevant concern for understanding is with the meaning of the behavior. The interpretative "sciences" can assume a truth claim on the part of their texts and must rely in part on an interpretative, linguistic tradition in understanding that claim. Similarly, in understanding the purpose of a law or government practice, we appropriately assume that the law has a sense and an intelligible function-and we rely upon a framework of collective understandings, a way of looking at, experiencing, and understanding the world in deter-

97 See R. UNGER, supra note 14, at 46-49, 81-83, 121-33 (discussion of liberalism as having the view that the whole is the sum of the parts).

98 Many theorists of various schools who disagree on many other points and even on the elaboration of this point agree that in crucial respects the task of understanding or interpreting a text or an action involves context and social practices and is not essentially oriented toward the subjective intent of the author or actor. I am neither able to discuss the point further or to give a breakdown of the various schools that would agree on the point. For relatively random examples, see S. CAVEll, MUST WE SaY What WE MEAN? (1976); H. GaDAMER, TRUTH AND METHOD (1982); D. HOY, THE CRITICAL CIRCLE (1982); P. WINCH, THE IDEA OF A SOCIAL SCIENCE AND Its Relation to Philosophy (1958); L. WitTgenstein, Philosophical Investigations (1958); Fish, Normal Circumstances, Literal Language, Direct Speech Acts, the Ordinary, the Everyday, the Obvious, What Goes Without Saying, and Other Special Cases, in INTERPRETATIVE SOCIAL SCIENCE 73 (P. Rabinow \& W. Sullivan eds. 1979); Ricoeur, The Model of the Text: Meaningful Action Considered as a Text, in id. at 243.

99 Not only is perfect identification with the other person without any reliance on one's own horizon a romantic fallacy, such an attempt is at best a limited undertaking. H. GADAMER, supra note 98 , at $335-36$. 
mining the meanings or purposes of a law. That this emphasis on contextual meaning is the appropriate interpretative enterprise-rather than looking merely for subjective motives-follows from several perspectives. The hermeneutic theorist would argue that the only interpretative understanding possible is a "productive" (not merely reproductive) activity that necessarily surpasses the author and must be "partly determined also by the historical situation of the interpreter."100 This emphasis also follows from the particular societal enterprise of which a written, authoritative text is a part. The role of law as a collective expression suggests the collective's responsibility for laws as that collective understands them. Moreover, the role of law as partially constituting the framework of social interaction again makes the contextual meaning, not the individual psychology of the enactors, most relevant.

The equality of respect model's emphasis on collective, political choice supports a focus on objective purpose for an additional reason. The social or contextual meaning of a law or act necessarily depends on the specific society that people create-on people's practices, on the politics of everyday life. Thus, the objective meaning or purpose of a law changes as people, in their attempt to make a better society, change the social context in which the law is understood. The capacity to give new meanings to, and thereby make objectionable, various social practices and artifacts, including laws, promotes people's ability to engage in politics and to choose or create their society.

The relation of political or social conflict and struggle to the contextual basis of meaning points to an issue of great practical importance that will not be adequately developed here. If a practice's meaning or purpose has a contestable, changeable content, consensus on its proper interpretation or understanding is unlikely in a politically (culturally or class) divided society. ${ }^{101}$ The appropriate objective might be to develop the interpretation or understanding that unconstrained or undistorted dialogue would produce-the understanding that would exist if we could free ourselves from the effects of domination. ${ }^{102}$ For two reasons, this objective cannot be achieved. First, it requires us to transcend our

100 Id. at 263; see also id. at 333-41 (nature of understanding); id. at 289-305 (legal hermeneutics); Linge, Introduction to H. GADAMER, PHILOSOPHICAL HERMENEUTICS at xxiii-xxvii (1977) (rejection of identification of meaning of text with author's intent; and description of Gadamer's hermeneutic, effective-history account of understanding); T. MCCARTHY, THE CRITICAL THEORY OF JURGEN HABERMAS 160 (1981) (Habermas argues understanding based solely on explication of subjectively intended meaning is impossible).

101 Moreover, any consensus that exists could represent "false consciousness," that is, could reflect conditions of coercion that cause the consensus not to represent people's true interests.

102 On the basis of a possible interpretation of Habermas, this describes his notion of an ideal speech situation. See R. GEUSS, THE IDEA OF A CRITICAL THEORY 65, 72 (1981); T. MCCARTHY, supra note 100 , at $307-10$. 
historical circumstances. The goal of the liberating or revolutionary imagination is to achieve this transcendence; but, such an attempt to escape the present can never be more than partially successful. Second, unless we assume a unique goal of history or a single, determinate content of the just society, there will not even theoretically be a single possible content of the hypothetical, undistorted dialogue; rather, the actual content of any undistorted dialogue depends on historical context, that is, the context of a yet unlived history.

What then is the proper objective of interpretive injury? Given that the understanding of a law. or practice that a just society would have or that undistorted community would uncover is indeterminate, one solution is for the judge (or interpreter) to discern and accept the currently dominant, arguably democratic understanding of a law, i.e., the understanding held by an informed, intelligent, "mainstream" individual (the law's "reasonable person"). This "solution" gives scope to politics while relying on a progressive dialectical process, to which equal protection adjudication hopefully contributes, in order eventually to supersede the existing understandings and transcend the existing distortions. Alternatively, possibly the judge should try to adjust for distortions, to understand the meaning or purpose of laws and official acts from a perspective of emancipation. Often this alternative will be furthered if the judge can understand laws or practices from the perspective of the disadvantaged-Justice Stone's "discrete and insular minorities"103 or Professor Ely's "they" in his "we/they" dichotomy. ${ }^{104} \mathrm{Or}$ possibly the judge's responsibility as an integrated person acting within her particular role-and predictably her action-will be intentionally to politicize judicial decisionmaking and to understand the meaning and purpose of the law in light of her interests. Although this approach may appear to be the least principled, if the judge's interests (and the appropriate role-based interests that she takes on) are in equality and emancipation then this approach would duplicate the earlier suggestion that the interpreter try to adjust for distortion. Despite their importance in refining a more precise conception of purpose, these issues go beyond my present attempt at developing equal protection theory and raise more difficult jurisprudential problems that I will not pursue here.

The equality of respect model's no subordinating purpose principle, in sum, focuses on a contextual or objective notion of purpose or meaning. This focus also provides the most coherent explanation for the Court's decisions. Although the Court often uses the language of sub-

103 United States v. Carolene Prods. Co., 304 U.S. 144, 152 n.4 (1938).

104 J. ELY, DEMOCRACY AND DISTRUST (1980). 
jective intent, its opinions can be best understood as treating objective or contextual purpose as the key constitutional concern. For example, the sexually based restriction on eligibility struck down in Weinberger $v$. Wiesenfeld ${ }^{105}$ could have resulted from a compromise among members of Congress all of whom subjectively had constitutionally proper objectives for supporting the benefit program. In finding that the law had an impermissible purpose, therefore, the Court must have implicitly adopted an objective purpose analysis. By ignoring the possibility that the law resulted from a compromise among properly motivated legislators, the Court implicitly indicated that the law's constitutionally relevant purpose is neither equivalent to its supporters' individual purposes-that is, the whole is not the sum of the parts-nor even necessarily congruent with any of the individual motives. ${ }^{108}$ Likewise, the Court's recent, repeated rereading of Palmer v. Thompson ${ }^{107}$ to hold "that the legitimate purposes of the ordinance . . . were not open to impeachment by evidence that the councilmen were actually motivated by racial considerations"108 indicates that contextually understood purposes, not subjective motives, are crucial. Thus, although subjective motives may be relevant in some circumstances, the Court clearly denies that motives (in contrast to objective purposes) are always the crucial concern.

Statements and arguments in other cases lead to the same conclusion. The Court has indicated that an improperly motivated government decision would not constitute an equal protection violation if the decision would have been the same absent the improper motive. ${ }^{109}$ If bad motives were themselves the key constitutional evil, the fact that the decision would come out the same regardless of motive could not undo the constitutional violation. In contrast, the fact that the decision would be the same often eliminates the necessity of understanding the government act, as opposed to the government actor, as invidious. ${ }^{110}$ If the bad motives were not official or overt aspects of the government's decision-

105420 U.S. 636 (1975).

${ }^{100}$ Baker, supra note 1 , at 1085-89.

107403 U.S. 217 (1971).

${ }^{108}$ Washington v. Davis, 426 U.S. 229, 243 (1976). The Court specifically reaffirmed this interpretation of Palmer while rejecting the relevance of legislative motive in Michael M. v. Superior Court, 450 U.S. 464, 472 n.7 (1981) (plurality opinion).

${ }^{109}$ Arlington Heights v. Metropolitan Hous. Corp., 429 U.S. 252, 270 n.21 (1976).

120 Justice Stevens has emphasized this objective or contextual analysis in several concurring decisions. In Washington $v$. Davis, he argued that it is unrealistic to require the victim to prove actual subjective intent; and, that it is unrealistic to invalidate merely because an improper motive affected a participant in the decisionmaking process. 426 U.S. 229, 253 (1976) (Stevens, J., concurring). In Mobile v. Bolden, Stevens suggested that "a proper test should focus on the objective effects of the political decision rather than the subjective motivation of the decisionmaker." 446 U.S. 55, 90 (1980) (Stevens, J., concurring in the judgment). 
making, the prima facie respect arguably due governmental action might justify an understanding of the law as having the permissible purpose that would have led to enactment in any event. In contrast, if the impermissible purpose were part of an interaction with the person discriminated against, for example in an administrator's discretionary decisionmaking, or were prominently displayed, for example in the legislative record, only invalidation of the rule or ruling would effectively repudiate the offensive public proclamation and thereby (partially) remove the stain. Thus, the fact that the "same" law would be enacted even if the enactors considered only permissible purposes should not save a law with an announced bad purpose. Nevertheless, an interpreter should generally accept a law's announced good purpose unless it is incoherent or implausible to understand the law in terms of the announced purpose-for example, because the law does not rationally relate to that purpose or because contextual features make clear that the publicly proclaimed purpose is a pretext. If, however, a government practice only seems coherent or explicable in terms of a discriminatory purpose, not only will the Court not require evidence that the government decisionmakers had bad subjective motives but also it will ignore plausible contextual evidence that the decisionmakers had not been or, at least, had not consciously been improperly motivated.111

Although the Court in Personnel Administrator v. Feeney ${ }^{112}$ spoke in terms of subjective motive, its suggested test was much more contextual. After indicating that the inevitable adverse consequences of the law on an identifiable gender group reasonably created an inference of discriminatory "intent," the Court said that the inference would not "ripen into proof" if the "impact is an essentially unavoidable consequence of a [legitimate] legislative policy."11s Thus, "ripening" depends not on evidence concerning subjective intent of the legislator but only on the context of the legislation. This contextual analysis suggests that the "reasonable, nondiscriminatory alternative" test should be interpreted as an aid in uncovering unconstitutional purposes: Given the existence

111 In Castaneda v. Partida, 430 U.S. 482 (1977), the Court rejected the assumption that Mexican American officials would not discriminate against Mexican Americans. Moreover, although the Court has emphasized a concern about intentional discrimination, once a prima facie case had been made (without any evidence relating to subjective motivation), testimony simply denying use of racial considerations-which would be the only direct evidence of subjective intent-would be insufficient rebuttal. Id. at 498 n.19. Instead, the discriminatory results would require explanation by way of evidence of "the way in which the commissioners operated and their reasons for doing so"- that is, by way of contextual evidence. Id. at 500 . Although Justice Marshall, in his concurrence, noted social science studies that report and explain such discrimination against one's own group, id. at $503 \mathrm{nn} .2$ \& 3 (Marshall, J., concurring), this discrimination often will not be at a conscious level, see supra note 96 .

112442 U.S. 256 (1976).

118 Id. at 279 n.25. 
of such an alternative, the challenged law (although not necessarily the legislators) can be best understood in terms of the impermissible purpose. This interpretation contrasts with an effects-oriented interpretation, which treats the reasonable, nondiscriminatory alternative test as a means to enable a balancing approach to use a marginal cost/benefit analysis in order to calculate more precisely the costs (the bad effects avoided by the alternative) and benefits (the advantages over the alternative) of adopting or maintaining the challenged law. Rather than engaging in such an instrumental cost/benefit calculation, the Court routinely looks for the purposes needed to make sense of the law ${ }^{114}$ and only strikes the law if one of those purposes is constitutionally objectionable.

The objective or contextual purpose analysis was probably most emphatically emphasized in Michael $M$. v. Superior Court. ${ }^{115}$ Justice Rehnquist's plurality opinion stated: "The question for us . . . is whether the legislation violates the Equal Protection Clause of the Fourteenth Amendment, not whether its supporters may have endorsed it for reasons no longer generally accepted."116 Then he reiterated the statement in United States v. O'Brien" ${ }^{117}$ that "[i]t is a familiar policy of constitutional law that this Court will not strike down an otherwise constitutional statute on the basis of an alleged illicit legislative motive."118 Whether or not the Court properly applied a contextual purpose analysis in these cases-the dissents and many commentators argue that it did not-neither the Court's language nor its tests are readily understood if one treats contextual purpose as merely evidence of the real constitutional concern, subjective intent; they are understandable only if the real concern is contextual or objective purpose.

The Court has not carefully analyzed situations where, although the governmental decisionmakers' immediate objectives are proper, their action responds to and accommodates rather than opposes prejudiced

114 See, e.g., Orr v. Orr, 440 U.S. 268 (1979); Weinberger v. Wiesenfeld, 420 U.S. 636 (1975). In Minnesota v. Glover Leaf Creamery Co., 449 US. 456 (1981), Justice Brennan, for the Court, said: "In equal protection analysis, this Court will assume that the objectives articulated by the legislature are actual purposes of the statute, unless an examination of the circumstances forces us to conclude that they "could not have been a goal of the legislation.' " Id. at 463 n.7 (quoting Weinberger, 420 US. at 648 n.16). The most obvious circumstance in which an asserted purpose should not be understood as the law's purpose is when the legislation would be instrumentally irrational given the asserted purpose. A contextual purpose analysis would never find a law unconstitutional because it is irrational but, instead, employs a rationality analysis, like the reasonable nondiscriminatory alternative test, merely to help identify a plausible purpose or meaning of a statute. But see United States R.R. Retirement Bd. v. Fritz, 449 U.S. 166, 184 (1980) (Brennan, J., joined by Marshall, J., dissenting).

115450 U.S. 464 (1981).

116 Id. at 472 n.7.

117391 U.S. 367, 383 (1968).

213 See 450 U.S. at 472 n.7; see also supra note 108. 
behavior of private citizens whose motives or attitudes would render the government's action unconstitutional if their "private" motives were attributed to the government decisionmakers. In Palmer v. Thompson, ${ }^{110}$ the dissent identified a pattern of official resistance to desegregation and a governmental practice of implicitly teaching blacks that their protests would be costly to their welfare. This pattern should have persuasively demonstrated that the officials' decision to close the municipal swimming pools was invidiously, racially motivated. ${ }^{120}$ The dissent's claim that the closing was unconstitutional becomes problematic, however, if one accepts the Court's conclusion that the purpose of the city's action was to preserve peace and avoid fiscal deficits. Or the dissent might fail if, using the Arlington Heights v. Metropolitan Housing Corp. principle, ${ }^{121}$ the city argued that even if the closings were racially motivated the same result would have followed from the proper concerns of safety and expense. On a subjective motive analysis, given the majority's view of the facts, the city's action would be acceptable because the officials' motives were proper; even accepting the dissent's claim that the city had exhibited official hostility to blacks, the closing of the pools was properly upheld because it would have resulted from the proper motives.

In contrast, an objective or contextual purpose analysis should find the closing unconstitutional. ${ }^{122}$ The safety and financial problems of keeping the swimming pools open are the result of the racist views or preferences of some of its citizens, preferences that would result in their engaging in violence or in their not frequenting integrated pools. The city's action gave these preferences a determinative role in its decisionmaking. The government action, the closing of the public swimming pools, would not have occurred except for the racially discriminatory attitudes or preferences of some members of the community. Moreover, the city knowingly and willingly conformed to, rather than reacted against, these preferences. Under these circumstances, one must understand the closing as a victory for the racist position. The officials' decision, even if not the officials themselves, must be understood as embodying a purpose to subordinate or denigrate or intimidate blacks. Like government action that restricts a person's opportunity to speak in order to avoid dangers created by a hostile audience, ${ }^{123}$ the city's action in

110403 U.S. 217 (1971).

190 See id. at 234-35 (Douglas, J., dissenting); id. at 258-71 (White, J., dissenting).

121429 U.S. 252, 270 n.21 (1977) (action sustained even if improperly motivated if it would have been the same without consideration of the improper motive).

122 The Court has since recast Palmer into an objective purpose case without analyzing the issues raised here. See supra note 108.

123 Cf. Feiner v. New York, 340 U.S. 315 (1951). The decisions in Feiner and Palmer may 
closing the pool ratifies and will be understood to ratify private discriminatory motivations. At least as long as other official responses were reasonably available, ${ }^{124}$ the city officials' action should be understood as having a discriminatory purpose. Basing official action on private citizens' discriminatory or invidious motives is constitutionally improper because the prevailing private preferences infect and, in context, should be understood to define the purpose of the law. Moreover, the closing is unconstitutional under Feeney's " 'because of,' not merely 'in spite of its adverse effects" test, ${ }^{128}$ since the closing occurred because of people's opposition to integrated swimming; and Arlington Height's caveat does not help the city since the closing would not have occurred at all but for people's racist motives. Of course, the racist context of the decision should not prevent the city from responding to legitimate safety or financial problems-it should only require that the closing, like the restrictions imposed on the speaker in a hostile audience context, occur only as a last resort and in a manner designed maximally to respect and protect, even at some public expense, ${ }^{128}$ the interests of those against whom the prejudiced motives are directed.

Some confusion exists over whether in a purpose analysis a law's purpose, and hence its constitutionality, can change over time. Given that the Constitution is as much (or more) directed to legislators (and executive-branch officials) as to courts, commentators have argued that it would be anomalous if a law could become unconstitutional over time even though the legislators had acted constitutionally when they passed the law. ${ }^{127}$ If the subjective motivation (or rationality) of the decisionmakers is the proper focus, then surely constitutionality depends on the legislators' subjective motivation at the time they enact a law. This conclusion, however, does not follow if the legislators' constitutional duty includes repealing laws that become invidious ${ }^{128}$-laws whose

be wrong for similar reasons. In both cases the Court explained the wrong result by misrepresenting the fact situations. Even given the majority's treatment of the facts, the result was also wrong for the reasons described in the text.

124 In an analogous situation, the proffered purposes of maintaining prison security and discipline did not justify racial segregation in prison; nevertheless, in particular circumstances, presumably as a last resort and a temporary expedient, racial tensions may be taken into account to justify short term segregation. Lee v. Washington, 390 U.S. 333 (1968).

123442 U.S. at 279 (1979).

128 The failure to spend some money to avoid a racially unjust situation in a society that otherwise spends large amounts to promote justice and protect people's rights would, in itself, indicate a contextually invidious purpose.

127 Linde, Due Process of Lawmaking, 55 NEB. L. REv. 197, 215-18 (1976). "If responsible lawmaking is the premise of review, the purpose against which the rationality of the means is tested must obviously be the purpose intended at the time of enactment." Id. at 216.

128 Linde points to the nonsensical results of testing laws on the basis of their rationality as applied at the present time in a specific place. His critique both of rationality review in general and of its application is persuasive. Linde, supra note 127. His argument is less forceful if the 
purpose or meaning changes in particular ways. The justification for a duty to repeal laws that develop an unconstitutional purpose or, more generally, for a duty for executive officials to treat such laws as void and for courts to invalidate them is the same as the justification for a ban on adopting laws that have an invidious purpose-such laws have no acceptable, present role in a legitimate collective order. Moreover, this duty does not shrink the sphere of legitimate, political choice-the factor which helped justify the focus on purpose rather than on effect-since the law could not currently be a proper object of political choice. In the Rawlsian original position, people could as rationally agree to impose a duty on legislators to repeal laws or on courts to void laws that come to have impermissible purposes as they could agree to prohibit the adoption of such laws.

Both technological developments and cultural politics can eliminate or change the contextual purpose or function of a law. The development of new technology that eliminates the safety hazards of slack action in long railroad trains could make a train-length-law, passed before the universal reliance on this new technology, no longer explicable as a safety measure. ${ }^{129}$ Alternatively, changes in normal practices in the trucking industry could make length regulations originally passed to promote safety and national uniformity no longer explicable in those terms and, instead, most comprehensible as a method of discouraging out-of-state trucking. ${ }^{130}$ Likewise, cultural politics may prevent us from accepting (or the state from claiming) that the purpose of a law requiring pregnant teachers to take a mandatory maternity leave is to insulate children from the sight of pregnant women. ${ }^{131}$ Presumably, during a

legislative or judicial duty is not to eliminate irrationality, which could become an all-consuming task, but to strike down laws that over time become contrary to a substantive constitutional standard. In fact, Linde recognizes that his argument does not apply to substantive review of laws. The objective purpose analysis, unlike a rationality or process analysis, operates as a substantive standard.

${ }^{129}$ Cf. Southern Pac. Co. v. Arizona, 325 U.S. 761 (1945); Brief for Appellant, vol. II at 141-42, Southern Pac.; Brief for the United States as Amicus Curiae at 40-41, Southern Pac.; Brief for the Ass'n of Am. R.Rs. as Amicus Curiae at 22, 27-28, Southern Pac. The best interpretation of the negative implications of the commerce clause is that it prohibits state laws directed at the interstate aspect of commerce. This interpretation identifies such laws either by finding facial discrimination or by finding a discriminatory effect that must be understood as the law's purpose after ruling out alternative explanations. In this sense, the inquiry is similar to the purpose analysis applied in the equal protection area. Taking a reverse example, in McGowan v. Maryland, 366 U.S. 420 (1961), the Court upheld a Sunday closing law against an establishment clause attack only because, in its view, the purpose of the closing law legislation had changed and had become acceptable over time. Id. at 431-37, 444-52.

1so Kassel v. Consolidated Freightways Corp., 450 U.S. 662, 679-87 (1981) (Brennan, J., joined by Marshall, J., concurring in the judgment).

131 See Gleveland Bd. of Educ. v. LaFleur, 414 U.S. 632, 641 n.9 (1974). In any event, from a perspective sensitive to sexist structures, such a purpose would itself present telling parallels to racial segregation and would properly be help impermissible. 
period when state law and private violence and intimidation effectively excluded blacks from voting, a desire to disinfranchise blacks would not motivate legislators to adopt an at-large electoral system ${ }^{\mathbf{1 3 2}}$-that goal having already been accomplished. Nevertheless, the purpose of excluding blacks from representation in government might provide the most plausible explanation of the law under current conditions. Thus, in separate opinions in Mobile v. Bolden, ${ }^{13 s}$ Justices Blackmun, White, Marshall, and Brennan found that a discriminatory purpose existed at the time of the suit, while Justice Stewart, announcing the judgment of the Court in an opinion joined by Chief Justice Burger, and Justices Powell and Rehnquist, noted the possibility that, on remand, the challengers might be able to prove a racially discriminatory purpose-although Stewart emphasized the need to find the "intent" of relevant state officials. ${ }^{134}$ Justice Stevens specifically rejected a focus on the subjective intent of the decisionmakers. ${ }^{135}$ In sum, no member of the Court in Mobile suggested that the law would be valid merely because the people who passed it had no discriminatory motives. ${ }^{136}$ Clearly, the Court believes that the purpose of a law can change as time changes its context.

Last Term Roger v. Lodge ${ }^{\mathbf{1 3 7}}$ realized the promise of Mobile. The Court upheld as not clearly erroneous the district court's finding that the at-large method of electing commissioners, " 'although racially neutral when adopted, is being maintained for invidious purposes." "138 "Maintaining" is an inapt verb to the extent that it suggests any active or even any conscious effort on anyone's part. Although, as Justice Stevens suggested in dissent, ${ }^{189}$ the Court's emphasis on intentional discrimination may suggest a concern with subjective intent, an objective or contextual purpose criterion makes much more sense of the result.

182 The actual purpose of these "reforms" may, however, have been to reduce working class influence on city government. See G. DOMHOFF, THE POWERS THAT BE 153-56 (1978).

183446 U.S. 55 (1980).

184 Id. at 71 n.17, 74-75 \& nn.20-21.

123 Id. at 90 (Stevens, J., concurring in the judgment).

138 See also Norwood v. Harrison, 413 U.S. 455 (1973) (law providing free textbooks to both private and public school children held invalid as to children attending racially segregated private schools even though the statutory scheme, first enacted in 1940, was not motivated by a desire to further racial segregation). The Court rejected the relevance of either good intentions or purposes, id. at 466, relying on Wright v. Council of Emporia, 407 U.S. 451, 462 (1972). The 5-4 decision in Wright, however, focused on effects in the context of remedying a recognized constitutional violation, not in the context of finding a new violation. Id. at 459, 461-62, 470. Thus, the Norwood rejection of purpose appears unexplained. Placing the 1940 enactment in the current environment, however, where state relations with discriminatory academies are a major focus of political concern, the Court could reasonably conclude that the present purpose of providing books to the segregated private schools is impermissible.

137102 S. Ct. 3272 (1982).

138 Id. at 3278 (emphasis in original) (quoting the district court's findings).

139 Id. at 3286, 3289-93 (Stevens, J., dissenting). 
Subjective intent implies there is someone who has the intent. But except to note that "as a practical matter" the state legislature would defer to the wishes of the county's state representatives on this issue, ${ }^{140}$ the Court did not even identify whose intent was constitutionally relevant. Moreover, none of the data cited by the Court concerning political participation or present and past discrimination within the county has any logical relation to the motives of the unidentified actors who are "maintaining" the at-large electoral system. Finally, the Court mentioned no evidence that anyone consciously considered either changing or retaining the at-large system-that is, there was no evidence that anyone had any conscious, subjective motives at all. ${ }^{141}$ In contrast, all the contextual evidence cited by the Court would be relevant in establishing the present meaning or in understanding the present objective purpose of the at-large voting system. Thus, the decision can best be understood to stand for the proposition that the objective or contextual purpose is the relevant constitutional equal protection criterion.

\section{Section Five Legislation}

Legislation and adjudication under section five of the fourteenth amendment have raised several troublesome problems that revolve around one central question: Does the grant of "power to enforce, by appropriate legislation, the provisions of this article,"142 allow Congress to create rights or impose responsibilities that the Court would not treat as otherwise constitutionally mandated? Of course, under the "necessary and proper" rationale, ${ }^{148}$ Congress constitutionally can create new rights as a means to secure rights or remedy violations of rights that the Court recognizes as constitutionally created. Except, however, for rights that are instrumental in securing or enforcing recognized constitutional rights or remedying recognized constitutional violations, this necessary and proper clause analysis does not permit Congress to create new substantive rights. For example, the necessary.and proper clause reasoning does not, at least not without crucial, controversial extra steps, justify a congressional prohibition on private interference with an individual's use of public facilities on a nondiscriminatory basis. ${ }^{144}$ If, as lawyers

140 Id. at 3280.

341 Id. at 3291-92.

148 U.S. CONST. amend. XIV, §5.

143 See, e.g., McCulloch v. Maryland, 17 U.S. (4 Wheat) 316 (1819); see also Katzenbach v. Morgan, 384 U.S. 641 (1966) (first rationale-that provision of vote could be the means to prevent unconstitutional discrimination in provision of public services).

144 A law prohibiting private racial discrimination that either impedes people's use of public facilities or, more generally, denies people opportunities on the basis of race could be understood as securing a right to have the state protect people against those types of private racial discrimina- 
generally assume, the individual's constitutional right is a right against state discrimination, then a congressional prohibition on private discrimination does not instrumentally "enforce," secure, or even relate to securing that right; instead, the prohibition creates a new, independent right. Nevertheless, a majority of the Supreme Court apparently has recognized congressional power to create this new right. ${ }^{145}$

The assumption that Congress has the power to create new, independent rights under the rubric of "enforcing" the fourteenth amendment raises a number of questions. Does this power make Congress the supreme interpreter of at least this part of the Constitution? Can Congress contract or only expand on the constitutional rights which the Court recognizes? Is Congress's power to expand rights limited to increasing the scope of state responsibility for discrimination that would be illegal if engaged in by the state-such as the private racial discrimination considered in Guest? Or does this power also enable Congress itself to define what counts as an improper denial of a judicially recognized fundamental right, such as the vote, or even allow Congress to establish new suspect classifications or fundamental rights, for example age or handicapped status or rights to food or employment? What principles determine the appropriate content or extent of congressional power? Obviously, the answers to these questions depend on the explanation of why Congress has power under section five to create new rights. An examination of this issue reveals that the equality of respect model offers a more plausible and coherent explanation for an expansive view of congressional power under section five than does an out-

tion. This right to state protection against private discrimination assumes that the state has a responsibility to guarantee that facilities are available on a nondiscriminatory basis rather than merely a responsibility not to discriminate itself. This right would require the state to take some responsibility for the treatment or opportunities a person actually receives rather than merely responsibility for government or state purposes. Although the Court in The Civil Rights Cases, 109 U.S. 3 (1883), contrary to many later interpretations, apparently assumed the existence of this broad duty, the dominant modern view and the view underlying United States v. Guest, 383 U.S. 745 (1966), is that $\S 1$ of the fourteenth amendment does not create such a duty. In Guest, the Court said: "It is commonplace that rights under the Equal Protection Clause arise only where there has been involvement of the State or of one acting under the color of its authority," id. at 755 , while leaving open the question of what "substantive . . . implementation [Congress could give] to any rights secured by [the Equal Protection] Clause." Id. at 754-55. Justice Clark's concurrence, however, in referring to Congress's power "to enact laws punishing all conspiracies-with or without state action - that interfere with Fourteenth Amendment rights," id. at 762, appears to assume the existence of fourteenth amendment rights with which private parties, acting alone, could interfere-that is, a right to be free of something more than objectionable state action.

148 See, e.g., United States v. Guest, 383 U.S. at 761-62 (Clark, J., joined by Black \& Fortas, JJ., concurring); id. at 781-84 (Brennan, J., joined by Warren, C.J., \& Douglas, J., concurring in part and dissenting in part). After a careful review of the cases, Professor Choper concludes that "a present head count on the existence and reach of [the Katzenbach v. Morgan, 384 U.S. 641 (1966),] 'definitional' branch produces substantial uncertainty." Choper, Congressional Power to Expand Judicial Definitions of the Substantive Terms of the Civil War Amendments, 67 MINN. L. REV. 299, 341 (1982). 
come equality model.

Arguably, section five only enables Congress to secure conditions required by other sections of the fourteenth amendment. Assuming an outcome equality perspective that views the equal protection clause of section one as mandating the structures of a just society, no other interpretation is plausible. To read section five as a positive grant of power to legislate expansions of equality would be undesirable since these expansions would involve deviations from the just levels mandated by section one. For example, a Rawlsian presumably would object to Congress increasing equality beyond the point that maximizes the wealth of the worst off-as well as objecting to the failure to reach that point.

Sensitivity to the limits of the institutional competence of each of the different branches of government could, however, lead an outcome equality theorist to advocate an affirmative section five legislative power. First, because the courts are not institutionally able to formulate or implement the necessary remedies, they will not be able to prohibit all the constitutional violations that the outcome equality theory identifies. ${ }^{146}$ For example, the judges might conclude that they cannot order the creation of new, comprehensive schemes to distribute health care, food, housing, or education even if they believe that equal protection requires these new, more expansive programs. Second, in some contexts, the courts may lack the information needed to determine or predict whether a particular regulation or program furthers the goals mandated by the outcome equality theory.

Justice Brennan, the chief architect of modern section five doctrine, has made statements that suggest this merger of the outcome equality analysis with an instrumentalist, institutional competence approach. Speaking for the Court in Katzenbach v. Morgan, ${ }^{147}$ Justice Brennan emphasized Congress's "specially informed legislative competence," its ability and "prerogative to weigh . . . competing considerations," and the possible bases upon which Congress could conclude that New York's law "constituted an invidious discrimination."148 In Oregon v. Mitchell, ${ }^{149}$ Justices Brennan, White, and Marshall emphasized that the "limitation on judicial review . . . is a limitation stemming, not from the Fourteenth Amendment itself, but from the nature of judicial review"-a limitation that "makes [the courts] an inappropriate forum for the determination of complex factual questions" but that

\footnotetext{
146 See supra note 6 and accompanying text.

147384 U.S. 641 (1966).

iss Id. at 656.

140400 U.S. 112 (1970).
} 


\section{"[has] no application to Congress."1so}

Although Justice Brennan's rhetorical emphasis on institutional competence suggests an underlying outcome equality perspective, this rhetoric does not jibe with the problems actually considered. His decisions make more sense if read as following the normal judicial practice of accepting congressional legislative power to make policy choices within a sphere of congressional authority rather than as approving greater congressional institutional competence to interpret the Constitution. ${ }^{151}$ In neither Morgan nor Mitchell did the challenged legislation represent a response to factual or remedial problems that could better be addressed by a legislative body than by a court.

First, as to factual problems, there is no reason to think that the determination of proper voting age turns on specific facts about its effect on achieving specific societal results. Nor does the difference between eighteen- to twenty-year-olds and older people seem as much a factual issue ${ }^{\mathbf{1 5 2}}$ as an issue of value judgment and line drawing. There was apparently no factual dispute presented in Mitchell. Likewise, in Katzenbach v. Morgan, although some weak, ambiguous historical evidence suggested that New York's English literacy requirement had an invidious purpose, the determination of this issue did not require complex instrumentalist factual judgments-the facts were of the type that courts normally handle. Moreover, as the dissent pointed out, Congress

180 Id. at 247-48 (Brennan, White \& Marshall, JJ., dissenting in part and concurring in part).

${ }^{152}$ Professor Cohen has advanced probably the most influential explanation of Justice Brennan's view that Congress can use section five to give new content to section one but cannot dilute rights established by the courts. Cohen, Congressional Power to Interpret Due Process and Equal Protection, 27 STAN. L. REV. 603 (1975). Cohen argues that Congress's affirmative exercise of section five power raises only issues of federalism-Congress is doing something that the state concededly could do. The courts should accept this exercise of power assuming that they have properly given up the role of limiting or even seriously reviewing the scope of the Constitution's delegation of legislative power to Congress. In contrast, a congressional limitation on a judicially recognized individual right is an exercise of power denied to the states; thus, the exercise does not merely transfer constitutionally acceptable legislative power from state into federal hands, but asserts an otherwise constitutionally unacceptable power to limit individual rights. Unlike federalism, individual rights constitute the prime area in which the courts should and do intervene. The results of Cohen's functional account parallel the conclusions I advocate. His analysis, however, does not explain why Congress should have, or whether a "conscientious legislator" should claim, this expansive legislative power. Moreover, writing before National League of Cities v. Usery, 426 U.S. 833 (1976), was decided, Cohen does not consider how to interpret section five if the Court revives judicially enforced federalism limits on congressional power.

182 "Section 5 empowers Congress to make its own determination [of whether the factual basis necessary to support a state legislative discrimination actually exists,]" and, if a "factual basis . . . does not exist . . . to remove the discrimination by appropriate means." Oregon v. Mitchell, 400 U.S. at 248 (Brennan, White \& Marshall, JJ., dissenting in part and concurring in part). The problem with viewing this as a factual investigation is that it seems clear that Congress's conclusion would be based more on how it evaluates the facts, on its value judgments, than on what the facts are. Whether differences between 18- and 21-year-olds justify the discrimination becomes, then, a normative judgment about what equality requires. 
apparently neither investigated nor considered these facts. ${ }^{153}$ Thus, the case hardly presents compelling circumstances for deference to Congress's capacity to make factual investigations or predictions. Basically, the congressional act represented a value judgment, not a factual judgment, that the state should not exclude certain educated, Spanish speaking people from the vote. In other words, in neither case did the need to make complex factual judgments about the impact of the state practice on the theoretically specified concept of equality (outcome equality) justify the exercise of congressional power. ${ }^{104}$

The other institutional-competence explanation of Congress's power under section five claims that courts cannot fully implement equal protection because they are not competent to order the necessary remedies and, therefore, that only Congress can give the clause its full scope. This explanation also is inapplicable in the context of the above cases. The Court could easily implement a decree finding unconstitutional the private discrimination in Guest, New York's English literacy tests in Morgan, or Oregon's restriction on eighteen-year-old voters in Mitchell. The Court's inaction must be attributed either to its judgment on the constitutional merits of these issues or to its view that the issues were matters for political choice, not to its incompetence to act. Therefore, at least in these cases, the outcome equality model cannot rely upon Congress's greater factfinding or remedial competence to explain the divergence between the Court's and Congress's recognition of fourteenth amendment rights. Congress's greater competence could only be based on a superior judgmental or interpretative ability. This conclusion, however, is troublesome. It undermines Justice Brennan's argument that Congress can expand but not contract Court announced rights. Moreover, many will rebel more generally at this form of institutional-competence analysis. They will find unappealing any constitutional analysis that concludes that judges should abdicate, in some situations, their duty to apply the constitution as they understand it.

The equality of respect model offers a straightforward alternative. The justification for recognizing congressional power to increase equality or to expand state responsibility for preventing private discrimination or otherwise expand the guarantees of the equal protection clause is that these expansions are plausible political choices that should be

183384 U.S. 641, 669 (Harlan, J., joined by Stewart, J., dissenting).

1se The irrelevance of complex factual issues refers only to Brennan's second rationale for Morgan. His first rationale, that voting rights would help remedy discrimination in the provision of public services (although there was no evidence that Congress was aware of any such discrimination, 384 U.S. at 669 (Harlan, J., joined by Stewart, J., dissenting)), fits easily into a necessary and proper clause remedial framework that may properly rely upon speculative factual hypotheses. 
open to the government. A self-defining, democratic polity should be permitted to pursue or promote a more extensive equality than that which is required as a prerequisite to legitimate governance-as well as be permitted to promote commerce and maintain defense. ${ }^{185}$ Under this interpretation section five, as a grant of legislative power to choose greater equality, does not just supplement section one's equal protection mandate (which results in the three principles discussed above). The substantive content of section five is a grant of legislative, not interpretative, power. Specifically, section five embodies a recognition that a democracy must be authorized to choose, as a policy goal, greater equality than legitimacy requires.

Obviously, this positive grant of legislative power should not include any authority to reduce the degree or forms of equality required for legitimacy. The strictures of section one should remain untouched. Since Congress would only be exercising legislative power-not "the power to define the substantive scope of the Amendment,"1s8 a power that Brennan's critics reasonably argue could not be limited in a principled fashion only to expansions of the amendment's substance-recognizing this congressional power would not reverse the premise accepted since Marbury v. Madison ${ }^{167}$ that the Court is the ultimate legal arbitrator of the Constitution. ${ }^{158}$ Instead, Congress would be choosing its own egalitarian policies. In reviewing Congress's enactments, the Court should only consider whether the acts in fact have an egalitarian objective purpose and do not violate section one or any other specific constitutional prohibition, not whether the enactments are proper interpretations of section one.

Section five's use of the word "enforce" arguably embarrasses this reading of the section as a general grant of legislative power to pursue equality. Under the equality of respect model's conception of equal protection, however, any seeming inconsistency disappears. The equality of respect model treats equal protection as more than simply a mandate of the institutional content that is necessary for the legitimacy of the political order; it is also an egalitarian ideal that places political responsibil-

188 One of the most unusual aspects of Justice Powell's opinion in Regents of the Univ. of Cal. v. Bakke, 438 U.S. 265 (1978), was that he thought it more permissible for a state to pursue educational diversity than for the state to promote a more racially integrated medical profession as a step toward creating a racially more egalitarian society. It is also curious that Justice Powell thought the Court should take over the school board function of determining whether particular measures would suffice to promote the desired diversity.

${ }^{160}$ Katzenbach v. Morgan, 384 U.S. at 668 (Harlan, J., dissenting) (emphasis omitted).

1675 U.S. (1 Cranch) 137 (1803).

198 See Oregon v. Mitchell, 400 U.S. 112, 204-05 (1970) (Harlan, J., concurring in part and dissenting in part); Katzenbach v. Morgan, 384 U.S. 641, 668, 671 (1966) (Harlan, J., dissenting). 
ity on people for its further elaboration. From this perspective, the directive in section five to "enforce" this ideal is both a directive to guarantee that minimal content required by section one and an invitation to realize further the ideal to the extent that people conclude further realization is wise. Congress's exercise of general legislative power to realize egalitarian goals greater than those mandated by section one is, therefore, a legitimate section five enforcement of equal protection. The basic distinction between the equality of respect and the outcome equality models-that the equality of respect model leaves more issues open to democratic decisionmaking-easily leads to this interpretation of section five as a grant of legislative power to promote equality.

Other aspects of the equality of respect model also suggest this interpretation of section five as a grant of power to legislate beyond court created rights. The specific content of the equality of respect model's mandate that society provide for just wants and avoid invidious purposes depends on societal practices and choices. In contrast to courts, which in determining the present content of constitutional mandates must take the existing context as a given, legislatures, as more political institutions, typically aim at creating that context. A key objective of politics is to comprehend and implement better interpretations of equality. ${ }^{150}$. The historically necessary incompleteness of any abstract theoretical interpretation of equality indicates that further advances require new practices; that is, a better understanding of equality can only come from politics and should be a goal of politics. The political system appropriately could decide to value and to create a new, greater degree of social equality that requires a recognition of new just wants or of a social minimum higher than presently recognized or a recognition of invidious purposes or meanings in presently accepted practices. The fourteenth amendment would be incomplete as an institutionalization of the equality of respect ideal without a provision authorizing and directing political actors to go beyond the existing, established notions of equality.

The possibility of congressional retreat from judicially mandated equal protection rights deserves further attention. The main theme above-that section one provides some of the necessary prerequisites of legitimacy while section five allows the political order to choose policies that promote a greater degree of equality-does not directly provide for the possibility of congressional retreat. Nevertheless, once one also recognizes that basic section one mandates take on content in a society-

${ }^{150}$ See O'Fallon, Adjudication and Contested Concepts: The Case of Equal Protection, 54 N.Y.U. L. REV. 19 (1979). 
specific context, the analysis becomes more complex. Some politically initiated reversals of equal protection rights may be possible-although only under rather unlikely circumstances and on a quite different rationale than the expansions. Given the supremacy of judicial review recognized in Marbury, neither Congress's reliance on new or more extensive or different information nor its greater institutional competence nor its independent normative views justify congressional repudiation of judicial mandates. Nevertheless, to the extent Congress's action changes society sufficiently that the meaning or purpose of a practice previously held to be unconstitutional or the content of societally recognized just wants changes, ${ }^{160}$ Congress could properly "retreat" from the courts' prior holdings. A retreat under these circumstances, however, does not imply that Congress can override the courts' judgment; rather it is justified by other political decisions of sufficient significance to change the context in which we understand equality. In these circumstances, a court itself should, given the opportunity, make the same retreat. Moreover, it is precisely this possibility of basic legislative changes of the social context that could likewise justify judicial action reversing previously correct holdings and finding new, constitutionally mandated content to equal protection.

\section{Other Doctrinal Implications}

The equality of respect model prohibits any government act or inaction that violates the model's normative principles. Since these principles are partially constitutive of a legitimate political order rather than specific goals to be attained, they require normative, not instrumentalist or cost/benefit, evaluations. This obvious point has several implications. Much of the articulated orthodox equal protection doctrinal framework

100 Consider the Court's suggestion that under some circumstances the freedom of choice plan struck down in Green v. County School Bd., 391 U.S. 430, 440-41 (1968), might be upheld. See generally supra notes 123-36 and accompanying text (discussing how purpose can change over time as context changes). Presumably if all judicial appeals (or maybe first appeals as a matter of right) were abolished in criminal cases and if this abolition were not itself unconstitutional as a denial of due process and if the abolition did not have an invidious purpose, equal protection would no longer guarantee convicted defendants an attorney for an appeal as a constitutionally based just want. See Douglas v. California, 372 U.S. 353 (1963). The analysis becomes even more interesting in other areas. Accepting Marshall's argument that education is a fundamental right (a just want), San Antonio Indep. School Dist. v. Rodriguez, 411 U.S. 1, 97-98, 110-17 (1973) (Marshall, J., dissenting) - a conclusion not rejected but merely avoided by a majority that concluded Rodriquez presented no issue of denial of the constitutionally mandated minimum of education even if the constitution mandated some minimum-one wonders what societal changes political bodies could legislate that would eliminate or change the fundamental status of education. Cf. M. WALZER, supri note 72, at 70, 76-77 (1983) (public drama festivals rather than schools were recognized as a just want in ancient Athens; given the purpose of education and the role of women, women did not need a formal education in medieval Jewish communities). 
is left pointless if not incoherent. (I refer only to "articulated doctrine" because the doctrine implicit in the Court's reasoning and results is closer to the equality of respect interpretation; in any event, the "articulated doctrine" seldom leads to any conclusions.) First, differing degrees of judicial scrutiny, if that means different constitutional standards for 'different problems, have no place in equal protection theory. Second, the Court has no authority to engage in the political task of determining the importance or substantiality of government purposes. Third, contemporary doctrine's emphasis on the instrumental rationality of government acts is not an appropriate constitutional concern of the Court. Neither the process model's heightened doubts about the "rationality" of political choices stemming from expectations of the inadequacies within the political process nor the outcome equality model's conclusion that only very compelling reasons justify deviations from otherwise mandated "end results" provides a relevant rationale for adopting the rhetoric of two-tiered or multi-tiered rationality review. "Rationality" tests have no point except to the extent that they aid the Court in identifying a law's purpose. Although the government's stupidity-which the rationality test apparently attempts to catch-is surely subject to political criticism, it does not deny equality of respect to any particular person or group of persons. Ends/means rationality analysis with its concern with the closeness of the fit between the legitimate ends sought and the actual means employed is irrelevant in the equality of respect theory. ${ }^{161}$ Rather than invoke ration-

101 In the context of "just wants," which are usually identified in part by finding government actions that exhibit an underlying judgment that the particular good or opportunity should be available to people who need it, a government limitation on the availability of the good or opportunity is justifiable only if the persons excluded are properly treated as not needing the goods or are properly subject to deprivation of the goods as a penalty for their conduct. Thus, in this context, equal protection requires a perfect fit, not between the classification and the state's purpose-which would be the relevant inquiry in a pluralist political process model-but between the law and the normative requirement that people's needs for these goods be met.

The more traditional version of ends/means, over-and-under-inclusive rationality analysis assumes that the courts should abide by the actual substantive conclusions of the pluralist political process, rather than test legislation against some independent conception of the general good. This traditional approach is often associated with Tussman and tenBroek's classic article, The Equal Protection of the Laws, 37 CALIF. L. REV. 341 (1949); and although most commentators who cite that article apparently assume that this purely means-oriented rationality review is consistent with, and possibly furthers, the pluralist political process, Tussman and tenBroek specifically emphasize the opposite. See id. at 350. The failure of many scholars to note Tussman and tenBroek's clear explanation that this fit analysis is incompatible with a pressure-group theory of politics is itself an interesting bit of intellectual history. This "misreading" may result from-and possibly illustrate-the grip that the pluralist or pressure group theory of politics has on our minds, our preference for apparently value neutral rationality or instrumental analyses, or the influence of teaching materials containing edited versions of articles. Cf., e.g., G. GUNTHER, CASES AND MATERIALS ON CONSTITUTIONAL LAW' 678-80 (10th ed. 1980) (quoting Tussman and tenBroek's fit analysis but leaving out their explanation that their equal protection analysis is inconsistent with a pressure-group theory of legislation and that their fit analysis assumes "some conception of 
ality tests of differing degrees of scrutiny, one should, as Justice Stevens has argued, ${ }^{162}$ evaluate all laws against the same standard.

Of course, the equality of respect model predicts that most invalidations will occur in areas of traditional strict scrutiny-but only because in these contexts the law often either embodies a purpose to subordinate or a meaning that denigrates particular groups of people, or denies or fails to provide for just wants.

The content and existence of guaranteed just wants has led the Supreme Court into a whole set of doctrinal issues that will be only briefly touched on here. ${ }^{163}$ Both the equality of respect model and some versions of the outcome equality model require that the state guarantee provision of certain goods and opportunities. The models differ, however, not only in how they justify these guarantees but also in how they identify them. Rather than being designed to maximize the position of the worst off, according to the equality of respect interpretation, the guarantees are designed to provide everyone the opportunity fully to participate in community life and to have a meaningful life as understood by their community. The lack of a maximizing requirement means that the distributional mandates of the equality of respect interpretation of equal protection will normally require fewer (and will never require more) guarantees for the poor than does the outcome equality model. More important, in the equality of respect interpretation, the content of the guarantee depends primarily on the community's specific values and self-conception, as evidenced by its changing social practices.

In a democratic polity, the goods that a person could claim as a matter of right generally would be only those that cultural practices and political decisions indicate ought generally to be available-at least this limitation applies unless the political decision not to provide for certain goods resulted from a desire to subordinate or exploit those who are forced to do without. (The general notion that individual rights should depend on community self-definition illustrates that the vital role of political struggle continues even if society has generally accepted and implemented the equality of respect interpretation of equal protection.) This "unless" caveat allows considerable room for objection within an equality of respect model-room, for example, for those who make a class critique of existing society to argue that the inadequacy of

a 'general good' as the 'legitimate public purpose' at which legislation must aim," 37 CALIF. L. REV. at 349-50).

162 Craig v. Boren, 429 U.S. 190, 211-12 (1976) (Stevens, J., concurring).

16s This topic requires considerably more development. To date, the most important analysis is in a series of articles by Professor Frank Michelman. See supra note 12. 
existing guarantees is an unjust, purposeful (whether or not subjectively intended) and, therefore, unconstitutional exploitation. ${ }^{\mathbf{1 6 4}}$ Thus, unlike the outcome equality model, which rests on an independent standard for measuring whether the society has guaranteed a proper level of just wants, the equality of respect model necessarily relies on variable societal judgments and practices to determine the content of just wants. Still, as in the outcome equality model, the crucial constitutional issue concerning the fulfilment of the appropriately specified just wants is the "effect" of the government action or inaction.

Several doctrinal conclusions follow from this description of the just wants guarantee. First, Justice Marshall was right in San Antonio Independent School District v. Rodriquez ${ }^{185}$ to look at various institutional practices to determine whether we recognize education as a fundamental right. He appropriately considered the treatment of education in state constitutions and in the decisions of the Supreme Court and its role and status in modern society. Second, the state should not deny a person's claim to provision of just wants unless the person is not in need of the resources ${ }^{\mathbf{1 6 6}}$ or the person has acted in a way that the state has a right to punish by denying those resources. Thus, in the context of just wants, rules that irrebuttably presume either a lack of need or the existence of wrongdoing must be rejected in favor of due process procedures that ascertain whether the state can properly exclude the person. ${ }^{187}$ Likewise, denial of just wants to those in need must be un-

184 This caveat emphasizes the need to develop ways of identifying purposes that may never reach the level of the actor's consciousness. Moreover, if the purpose can only be seen within the perspective of a particular world view, different conclusions may be reached from different perspectives within a class divided society. See supra text accompanying note 97.

183411 U.S. 1, 110-17 (1973) (Marshall, J., dissenting).

168 "It is a purpose of the ancient institution of property to protect those claims upon which people rely in their daily lives . . . " Board of Regents v. Roth, 408 U.S. 564,577 (1972). In Arnett v. Kennedy, 416 U.S. 134 (1974), Justice Rehnquist, announcing the judgment of the Court in an opinion that did not find a property right with which the employment dismissal process interfered, cited parts of Roth adjoining this quoted passage that noted positive law sources of property rights but he excluded this statement, id. at 151; Justice Marshall's dissent, joined by Justices Douglas and Brennan, ignored the portion that Justice Rehnquist cited but highlighted the quoted statement, id. at 208; in the middle, both ideologically and in location in the U.S. Reports, Justice Powell's concurrence, joined by Justice Blackmun, cited a lengthy passage that included both the portions cited by Justice Rehnquist and by Justice Marshall, id. at 165 .

${ }_{187}$ See, e.g., United States Dep't of Agriculture v. Murry, 413 U.S. 508, 514 (1973) (overturning an irrebuttable presumption denying food stamps to a certain category of households). Although not all the irrebuttable presumption cases fit this mold, many of the cases invalidating irrebuttable presumptions involve a substantive constitutional conclusion that either (a) in the given context the person has a right to something absent wrongdoing or lack of need or (b) that the general rule penalizes or impliedly makes a negative judgment about the exercise of a constitutional right. The cases spawned considerable confusion, and presently the doctrine is apparently and, I think, improperly out of fashion. See, e.g., Weinberger v. Salf, 422 U.S. 749 (1975). Commentators complained that, even without being in a context requiring strict scrutiny, the irrebuttable presumption doctrine required not only a close but a perfect fit. Moreover, since the court decisions strike down rules, apparently for being "over inclusive," commentators often consider 
derstood as a penalty (or coercion) rather than encouragement. The denial of state funding for abortions amounts to coercion rather than encouragement of childbirth not because of the effect of the denial on a woman's will but because society has recognized, if it has, that at least basic levels of noncosmetic medical care are a just want. ${ }^{168}$ (Using the no-impermissible-purpose principle of equal protection, the denial of abortion funding would also be impermissible if the purpose of the restriction was to disparage or subordinate a person for her exercise of a constitutional right). Likewise, the state would have unconstitutionally penalized the exercise of the right to travel, to change one's residence, if it denied just wants to members of a community as a consequence of these members' moves ${ }^{169}$ or if it denied them other resources or opportunities because of a negative judgment about them or their exercise of the right to move. ${ }^{170}$

them as equal protection cases improperly labeled as due process. See, e.g., Note, The Irrebuttable Presumption Doctrine in the Supreme Court, 87 HARV. L. REV. 1534 (1974); Note, The Conclusive Presumption Doctrine: Equal Process or Due Protection?, 72 MICH. L. REV. 800 (1974); Note, Irrebuttable Presumptions: An Illusory Analysis, 27 STAN. L. REV. 449 (1975). This is not quite right. As Rehnquist's positivist attack on both procedural due process, see, e.g., Arnett v. Kennedy, 416 U.S. 134 (1974) (Rehnquist, J., plurality opinion); but cf. Logan v. Zimmerman Brush Co., 455 U.S. 422, $431-32$ (1982) (Court continues to reject Rehnquist's positivist critique), and irrebuttable presumptions, see, e.g., Murry, 413 U.S. at 525-27 (Rehnquist, J., joined by Burger, C.J. \& Powell, J., dissenting); Cleveland Bd. of Educ. v. LaFleur, 414 U.S. 632, 657-60 (1974) (Rehnquist, J., joined by Burger, C.J., dissenting); Jimenez v. Weinberger, 417 U.S. 628, 638-41 (1974) (Rehnquist, J., dissenting), has shown, the Court in due process cases, as well as in irrebuttable presumption cases, typically rejects substantive governmental value judgments embodied in positive rules, see L. TRIBE, AMERICAN CONSTITUTIONAL LAW $\S \S 10-10,10-12$, at 525-26, 534-35 (1978) (noting necessity of, and defending the propriety of, Court using substantive values beyond those embodied in positive law); Michelman, Formal and Associational Aims in Procedural Due Process, in DUE PROCESS: NOMOS XVIII 126 (1977), and then the Court requires due process hearings before the government can dispose of the person's property or liberty interest. In a sense, equal protection - or, at least, the equality of respect premise - often enters into the due process analysis as the basis for finding that despite positive law that would eliminate her claim, a person has a right to the benefit unless specific facts, which must be properly identified, for example in the due process hearing, exist. Although the solution is different, the Court's value judgments embodied in their due process decisions are often the same as those implicit in the equality of respect model's just wants guarantee. See, e.g., Murry. The Court's observations in Goldberg v. Kelly, 397 U.S. 254 (1970), emphasize these values. Compare, for instance, the equality of respect model's just wants guarantee with the Court's holding in Goldberg that recipients must be given a due process hearing before their benefits are terminated. In the words of the Court:

Welfare, by meeting the basic demands of subsistence, can help bring within the reach of the poor the same opportunities that are available to others to participate meaningfully in the life of the community. . . . The same governmental interests that counsel the provision of welfare, counsel as well its uninterrupted provision to those eligible to receive it; pre-termination evidentiary hearings are indispensable to that end.

Id. at 265 (emphasis added).

${ }_{183}$ Cf. Harris v. McRae, 448 U.S. 297 (1980); Maher v. Roe, 432 U.S. 464 (1977).

${ }^{269}$ Memorial Hosp. v. Maricopa County, 415 U.S. 250 (1974); Shapiro v. Thompson, 394 U.S. 618 (1969).

170 Cf. Sosna v. Iowa, 419 U.S. 393 (1975) (The waiting period to get a divorce imposed on new residents apparently was not a penalty because there was no generally recognized right to get 
At this point, caution in the further elaboration of the model is needed. It is relatively easy, I think, to show that "the" or, at least, "an" evil of all the laws that the modern Court has struck down for violating equal protection either denied something that was arguably a just want or embodied a subordinating or disparaging purpose or meaning. Still, both the general meaning of equality of respect and the specific meaning of disparaging or subordinating purpose are quite slippery. The general principle is that the government is forbidden to evaluate a person negatively on the basis of factors over which she has no control or on the basis of participation in practices in which she has a fundamental right to engage. A complete elaboration of this equality of respect standard might have much broader doctrinal implications than the holdings of existing case law. Several questions deserve specific attention. First, does the state always show disrespect when it permits factors over which people have no control to limit their life prospects? For example, is equality of respect necessarily violated when people's unequal life prospects in part result from the unequal social-economic circumstances into which they are born, from the fact that their society values some talents and qualities more than others, or from factors such as height, eyesight, or particular forms of beauty and innate intelligence? Second, does the state violate equality of respect when it limits, burdens, or rewards particular activities in a way that favors people with particular preferences? A hundred years of psychological and sociological inquiry emphasize that both a person's inclinations and capabilities depend, at least in part, on socially determined conditioning. Likewise, the person's value (or use) to other people depends on the other people's conditioning and various collectively maintained practices. Does a meritocracy that rewards or punishes socially determined (or inherited) talents and attitudes ever or always deny people equality of respect? Probably the right answer to these questions is: "Not necessarily."

A society's practices, its laws and institutions, inevitably favor some individual behavior or some conceptions of the good life over others. Not only is any search for a neutral set of laws and institutions or for any equality of advantage doomed, but, at least according to the equality of respect model, people's right to participate politically in choosing what is to be favored is basic. Given that the collective inevitably does and has a right to promote particular conceptions of the good society, its practices will necessarily make many outcomes turn on what

a divorce within a specific amount of time and the Court concluded that non-invidious state purposes justified the waiting period.). 
a person "does," although not necessarily on its evaluation of her worth as a person-and this follows irrespective of whether a person can control these acts. ${ }^{171}$ For example, the collective could forbid a blind person from piloting a plane-not because of her lesser significance as an end or her worth as a person (judgments which would normally be implicit if she were so restricted because of being black or a woman) but because of what she does or cannot do-even though her inability to see the runway may be wholly outside her control.

Only this collective power to make the benefits that are available to and burdens that are imposed on the individual turn on acts enables society to reward and, thus, presumably to reinforce socially desired behavior and to further collectively desired goals. The collective's right to favor its chosen conceptions of the good also permits adoption of other practices that differentially affect people's opportunities independently of their acts. Even though inheritances leave some people with bleaker life prospects than others, the collective could justify inheritance as a means to promote desired features of family life or to further economic development. Of course, the society could instead conclude that desirable social features of a more egalitarian society not only justify disallowing or greatly restricting inheritances but also justify providing for even greater equality of life prospects than would result from Rawlsian principles. Moreover, the equality of respect model forbids justifying an inheritance system as a means of preserving class or family dominance. Finally, even if we choose to praise, honor, and reward exceptional performances (and to be disappointed by below. average performances), we should structure our institutions in a manner that does not treat those at the top of the praise, honor, or reward system as intrinsically more worthy. ${ }^{172}$ Nevertheless, all institutional structures and political choices will limit the prospects of some people more or less

${ }^{171}$ When we treat a person as unable to control her acts, for example, because of her intelligence, eye sight, or culturally created attitudes, judging the person's ethical worth on the basis of the acts is improper. Nevertheless, both the collective's and often the individual's interests are furthered by restricting or encouraging particular activities. One need only compare how, in family life, unequal restrictions, benefits, and responsibilities that relate to differential capabilities or opportunities do not automatically corollate with normative praise and blame or with attributions of worth.

172 If praise, honor, and reward are allowed, it may not be immediately clear what a prohibition on treating people as intrinsically more or less worthy would mean. The utilitarian might argue that the prohibition rules out treating some preferences, or the preferences of some people, as more significant than others. The democrat could make the same reply in respect to people's votes or the organization of power and rights of participation. Our Constitution illustrates this notion when it forbids the United States from granting any title of nobility. U.S. CONST. art. I. § 9. Waltzer provides an interesting elaboration on permissible inequality in his defense of "complex equality." He argues that the primary concern is to not allow distributions within one sphere-for example praise and honor in the realm of athletic or intellectual achievement-to control distribution within some other sphere. M. WALZER, supra note 72, at 17-20, 28. 
than other permissible structures and choices.

Allowing unequal life prospects denies equality at a fundamental level. An egalitarian theory that permits this should be troublesome. Nevertheless, the possibility of justifying some of these inequalities necessarily follows from the rejection of outcome equality models and from the conclusion that respect for people requires allowing for political or collective choice. The equality of respect model accepts inequality (1) if the inequalities result from choices made within a context that treats everyone as an equal (democracy), (2) if the purpose or significance of the collective choices is to promote some affirmative notion of the "good society," a purpose that excludes valuing this inequality itself as an aspect of this "good society," and (3) if everyone is guaranteed at least the basic minimum of just wants.

\section{CONCLUSION}

These comments do not pretend to resolve the problems presented in recent equal protection cases or to claim that a proper analysis, even by those who adopt the equality of respect approach, will be either obvious or uncontroversial. Rather, my claim is that the equality of respect model provides more and better guidance than either neutrality and process models or outcome equality models. Moreover, I claim that the equality of respect model elaborated here explains better than the other models our best normative intuitions concerning the proper content of our constitutional order-intuitions that find consistent though incomplete embodiment in the Court's otherwise difficult-to-justify equal protection decisions. 